
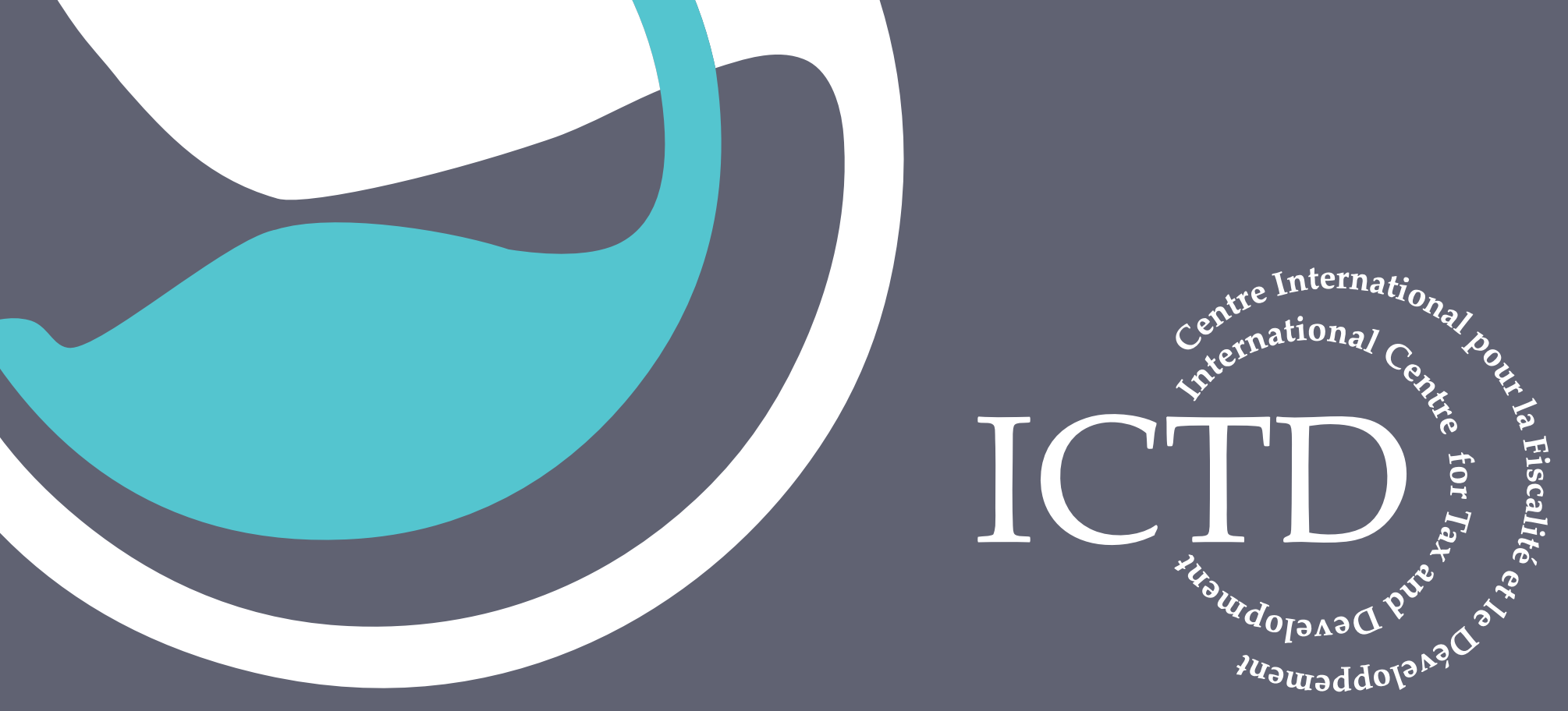

Working Paper 53

\title{
Taxing Multinational Enterprises as Unitary Firms
}

Sol Picciotto

June 2016 


\section{ICTD Working Paper 53}

\section{Taxing Multinational Enterprises as Unitary}

Firms

Sol Picciotto

June 2016 
Taxing Multinational Enterprises as Unitary Firms

Sol Picciotto

ICTD Working Paper 53

First published by the Institute of Development Studies in June 2016

(C) Sol Picciotto 2016

ISBN: 978-1-78118-298-7

The author of this paper grants to the IDS and the ICTD a perpetual, irrevocable, worldwide, royalty-free, non- exclusive licence or sublicence, to reproduce, communicate to the public, use, adapt, publish, distribute, display and transmit the Work in any and all media, and to sublicense others (including the Crown) to reproduce, communicate to the public, use, adapt, publish, distribute, display and transmit the Work in any and all media, for non-commercial purposes and with appropriate credit being given to the author and ICTD funders.

A catalogue record for this publication is available from the British Library.

This work has been licensed by the copyright holder for distribution in electronic format via any medium for the lifetime of the OpenDocs repository for the purpose of free access without charge and can be found at http://opendocs.ids.ac.uk/opendocs/.

Also available from:

International Centre for Tax and Development,

Institute of Development Studies,

Brighton BN1 9RE, UK

Tel: +44 (0) 1273915637 Fax: +44 (0) 1273621202

E-mail: info@ictd.ac

Web: www.ictd/en/publications

IDS is a charitable company limited by guarantee and registered In England (No. 877338) 


\title{
Taxing Multinational Enterprises as Unitary Firms
}

\author{
Sol Picciotto
}

\section{Summary}

This paper explores the issues raised for international tax rules of explicitly treating multinational enterprises (MNEs) as single or unitary firms. It first briefly explains why reform of international corporate taxation is important particularly for developing countries, then outlines the flaws in the current system. It discusses the impetus created for reforms, and the political and institutional dynamics of the tax treaty system. An evaluation is provided of the results of the G20/OECD project on base erosion and profit shifting (BEPS), focusing essentially on the extent to which they moved towards a unitary approach, and the problems created by their continued adherence to the independent entity principle. It then outlines several proposals which, in different ways, would apply a unitary approach to MNEs. The remainder of the paper focuses more particularly on one variant: unitary taxation with formulary apportionment - this was the focus of the ICTD's research programme, which resulted in the outputs discussed here. It outlines the main findings on optimal design of an international formulary apportionment system, evaluates the evidence about its possible effects on national tax revenue, and considers the possibilities and prospects for adoption of such a system regionally.

Keywords: international tax; multinationals; unitary; BEPS; transfer pricing.

Sol Picciotto has taught at the universities of Dar es Salaam (1964-68), Warwick (19681992) and Lancaster (1992-2007), where he is now emeritus professor. He is the author of International Business Taxation (1992) and Regulating Global Corporate Capitalism (2011), several co-authored books, and numerous articles on international economic and business law and regulation, as well as state theory. He is coordinator of the BEPS Monitoring Group, and Chair of the Advisory Group of the ICTD, with which he has conducted research on international tax. 


\section{Contents}

Summary 3

Acknowledgements

Acronyms

Introduction $\quad 6$

$1 \quad$ The importance of the issue, especially for developing countries $\quad 7$

$2 \quad$ Flaws in the system, and the impetus for reform $\quad 8$

$3 \quad$ The politics and technocracy of the BEPS process 11

$4 \quad$ Appraisal of the BEPS project outputs 14

$\begin{array}{lll}4.1 & \text { Hesitant moves towards a unitary approach } & 15\end{array}$

$\begin{array}{lll}4.2 & \text { The need for more radical changes } & 17\end{array}$

4.3 Attribution of profits: transfer pricing and functional analysis 18

4.4 Conclusions on the BEPS project 21

$5 \quad$ Options for adopting a unitary approach 22

5.1 Residence-based worldwide taxation (RBWT) 22

5.2 A destination-based corporate tax 23

$\begin{array}{lll}5.3 & \text { Other alternatives } & 24\end{array}$

$6 \quad$ Unitary taxation with formulary apportionment 25

6.1 The taxable nexus: unitary business or unitary enterprise?

6.2 Calculation of the tax base: tax and accounting rules 26

$7 \quad$ The choice of an apportionment formula 27

7.1 The formula and tax competition for investment 27

$\begin{array}{lll}7.2 & \text { Effects of the formula on tax revenue } & 29\end{array}$

$8 \quad$ Could formulary apportionment be adopted regionally? 30

$9 \quad$ Conclusions $\quad 32$

$\begin{array}{ll}\text { References } & 34\end{array}$ 


\section{Acknowledgements}

This paper has greatly benefited from the contributions of all the researchers involved in the ICTD international tax programmes. I am especially grateful to Michael Durst, who contributed considerable material to earlier drafts of this paper, much of which remains, and to Kim Clausing and Marcus Valadão for comments on the draft. I am also grateful to Jeff Kadet for his careful reading and comments, as well as for other collaborations; and to Mick Moore and Wilson Prichard for their insightful evaluations. Responsibility for the paper remains mine, and comments are welcome to <s.picciotto@lancs.ac.uk>.

\section{Acronyms and tax terms}

BEPS base erosion and profit shifting: a term coined by the OECD in 2012, to refer to the tax avoidance techniques used by MNEs to reduce their overall taxable profits, and shift profits from high- to low-tax countries

$\mathrm{CbCR} \quad$ country-by-country report (required under changes to the OECD Transfer Pricing Guidelines, to be filed by the ultimate parent entity of any MNE with a turnover greater than 750 million euros, and sent to tax authorities of every country where it declares a taxable presence, subject to conditions to protect confidentiality and appropriate use)

CFC controlled foreign corporation (a foreign subsidiary, the income of which may be treated as included in the parent's taxable profits)

CIT corporate income tax

CPM cost plus method (one of the five accepted transfer pricing methods)

CUP comparable uncontrolled price method (one of the five accepted transfer pricing methods)

DBCFT Destination Based Cash Flow Tax

EAC East African Community

EBITDA earnings before interest, tax, depreciation and amortisation (a widely-used accounting concept of corporate income)

G20 the Group of 20 leading states

GDP gross domestic product

ICTD International Centre for Tax and Development

IMF International Monetary Fund

MNE multinational enterprise

OECD Organisation for Economic Cooperation and Development

PE permanent establishment (a concept which defines the degree of presence of a foreign corporation in a country that gives rise to taxable presence - basically a fixed physical base for at least six or twelve months)

PSM profit split method (one of the five accepted transfer pricing methods)

RBWT residence-based worldwide taxation (also referred to as a full-inclusion CFC regime)

RPM resale price method (one of the five accepted transfer pricing methods)

TFDE Task Force on the Digital Economy (set up under BEPS Action 1)

TNMM transactional net margin method (one of the five accepted transfer pricing methods)

TPGs Transfer Pricing Guidelines

VAT Value Added Tax 


\section{Introduction}

This is one of a collection of papers aiming to contribute to the ferment of debate about the international tax system and its reform. They result from work by an international network of researchers supported by the International Centre for Tax and Development (ICTD). This research programme was conducted in parallel with the project on Base Erosion and Profit Shifting (BEPS) carried out through the OECD for the G20, and our work has been published in tandem with the reports from that project.

The G20/OECD project was clearly very different from an academic research programme. The BEPS project had the extremely ambitious aim of achieving, within a very tight timescale of some thirty months, consensus among a very large group of governmental tax authorities on reforms that could achieve a major reorientation of international tax rules. Given those constraints the final package was clearly a major achievement, which is a tribute to the determination and dedication of the officials involved.

The BEPS outputs aim to strengthen the system, and give better tools to tax authorities if they have the capacity and will to use them. Overall, however, the proposals are a patch-up of existing rules, making them even more complex and dependent on technical expertise to administer, and do not tackle in a coherent way the more fundamental flaws of the system. Nevertheless, this is an important first step on a longer road. The G20 project itself is continuing, both to supervise and coordinate implementation and to work on some key issues that were not dealt with in its main phase. Indeed, the BEPS project's outputs have not resolved fundamental problems of how to apportion MNE profits, especially in the digitalised economy. We hope that our research will help to inform these policy debates.

The continuing BEPS project agenda requires closer examination of the fundamental question posed by taxation of multinational enterprises (MNEs): the criteria for apportioning the tax base among the various countries where such firms have business activities. The G20 mandate for the BEPS project requested that international tax rules should be reformed to ensure that MNEs would be taxed 'where economic activities occur and value is created' (G20 2013: 4). This implied that MNEs should be treated in accordance with the business reality that they operate as single firms. Although the final BEPS project proposals did not accept this explicitly, in some respects they did move in that direction. However, on the crucial question of criteria for allocating profits, the proposals remained unclear and complex. Hence, although they open up a new road for the international tax system, the direction of travel is uncertain.

This paper explores the issues raised for international tax rules of explicitly adopting a unitary approach to MNEs. The next section briefly explains why reform of international corporate taxation is important particularly for developing countries. Section two outlines the flaws in the current system, and the impetus created for reforms. Section three discusses the political economy of the international tax treaty system, and of its reform. Section four provides an evaluation of the BEPS project proposals, focusing essentially on the extent to which they moved towards a unitary approach, and the problems created by their continued adherence to the independent entity principle. Section five outlines several proposals which, in different ways, would apply a unitary approach to MNEs. Section six focuses more particularly on one variant: unitary taxation with formulary apportionment. This was the focus of the ICTD's research programme, which resulted in the outputs which will be discussed here. Section seven evaluates the evidence about the possible effects of formulary apportionment on national tax revenue. Section eight considers the possibilities and prospects for adoption of such a system regionally, and Section nine concludes. 


\section{The importance of the issue, especially for developing countries}

Although opinions differ about the desirability of corporate income taxation as an abstract economic question, restoring its effective application to the largest and most powerful global firms is, in practice, an important goal of public policy. This is especially the case for developing countries, for several reasons.

First is the effect on government revenue. The percentage of government revenue derived from corporate income tax (CIT) varies, but it is fiscally significant in virtually all countries. Low-income countries in particular are generally more dependent on CIT, which on average accounts for 16 per cent of their revenue compared to 8 per cent for high-income countries (Crivelli et al. 2015). In most developing countries the formal economy is dominated by foreign-owned firms, while much domestic economic activity occurs informally with few if any books and records maintained. This makes it harder for governments to raise revenue from individual income taxes and consumption taxes. For these countries, corporate taxation, and especially taxation of the profits of foreign-owned companies, represents a substantial portion of the potentially available revenue base. These countries cannot afford to sacrifice large proportions of their corporate tax bases, and the perpetuation of international tax avoidance, now referred to as base erosion and profit shifting (BEPS), therefore poses a significant national hardship for them.

Secondly, restoring the integrity of corporate taxation is important also for its indirect impact on revenue, as corporate tax avoidance undermines public confidence in the legitimacy of taxation more generally. This has become particularly evident in developed countries due to the fiscal crises and resulting damage to faith in public institutions following the financial crash of 2008-9. These concerns greatly contributed to the political impetus leading to the BEPS project. Public confidence in the fairness of taxation, and of CIT in particular, has been greatly shaken by the significant evidence of considerable revenue losses due to international avoidance, especially from countries with comparatively higher CIT rates. An analysis by Clausing based on the comprehensive data available for US-based MNE corporate groups suggests significant and increasing losses from such avoidance for the US government, reaching to between $\$ 77$ billion and $\$ 111$ billion annually by 2012 . Her more speculative extension of these calculations to MNEs based in other countries suggests losses for all such countries (including the US) of perhaps $\$ 280$ billion (Clausing 2015). Estimates by International Monetary Fund (IMF) economists using a different approach suggest that the long-run losses for advanced economies are in the order of 0.6 per cent of their GDP, but proportionately three times greater in developing countries, reaching almost 2 per cent of GDP (Crivelli et al. 2015).

Developing countries also have a very different perspective on taxing MNEs than do developed countries. Firstly, they are mainly capital-importing countries, and hence host countries for MNEs. Tax treaties essentially restrict rights to tax income at source, in the interests of encouraging reciprocal international capital flows. For countries that are capitalimporters they impose asymmetrical obligations, to the point that they have been described as a poisoned chalice for developing countries (Brooks and Krever 2015; Hearson and Kangave 2016).

Yet, for the past half-century the formulation of international tax rules has been dominated by the developed countries of the OECD, with the UN Committee of Tax Experts playing only a secondary role (Picciotto 2013). The BEPS project partly bridged this gap, because it was taken up by the G20. Hence participation was extended to include the eight non-OECD G20 
countries, ${ }^{1}$ and subsequently a further fourteen developing countries were also invited to join. ${ }^{2}$ In February 2016 an Inclusive Framework was established: this allows any country to join in the continuing BEPS agenda as Associates, turning the OECD Committee on Fiscal Affairs into a global tax body for some purposes. Nevertheless, the OECD countries set the scope of the project, which explicitly excluded any reconsideration of the allocation of taxing rights between residence and source countries. In practice the issue was hard to avoid, especially as many OECD countries have experienced the difficulty of taxing foreign-based internet companies and service providers. Inevitably, the BEPS discussions and negotiations were dominated by the concerns of the large countries that are home to MNEs.

Thirdly, developing countries need tax rules that as far as possible can be administered easily, without the need for specialist and highly-trained staff applying subjective judgements. Recognising that some of the BEPS proposals would be difficult for developing countries to apply, the G20 Development Working Group was tasked with the development of toolkits on key aspects. This work has now been given to a Platform for Collaboration on Tax, which will coordinate. Yet it is legitimate to ask whether, rather than tools to adapt rules which are formulated by and for richer countries, it would not be better to investigate alternative approaches that might be more suitable for poor and less developed ones. This has also been the focus of ICTD research, some of which will be discussed further below. ${ }^{3}$

Finally, it is important to bear in mind that many of the techniques of international tax avoidance entail making use of the tax haven and offshore finance and secrecy system. These same facilities are also used for a much wider range of activities, including capital flight and concealing the proceeds of corruption and crime, which are also especially damaging for developing countries (High Level Panel 2015). The estimates that have been made by various parties of the magnitude of illicit flows through this system clearly far exceed the sums involved in corporate tax avoidance, and the bulk of those flows do not involve direct losses of government revenue. Nevertheless, there are links between corporate tax avoidance and the more general illicit flows, particularly as both take advantage of the same facilities and techniques. Furthermore, it can be said that the growth of a culture of increasingly aggressive tax planning, and its toleration as a valid business strategy, have also affected the boundaries of acceptable behaviour in other areas of regulation. If international tax reform could remove the incentives for MNEs to use the offshore system, it would clearly be a significant step towards ending the wider damaging effects of this system.

\section{Flaws in the system, and the impetus for reform}

The role of international tax avoidance in the creation and continuation of the tax haven and offshore secrecy system can be traced to a fundamental flaw in the international tax rules, designed almost a century ago. These rules were primarily aimed at international portfolio investment, the dominant form at that time. Hence, they gave the primary rights to tax business profits (so-called 'active' income) to the country where the business was located, while returns on investment (interest, dividends, etc., referred to as 'passive' income) should be taxed in the country of residence of the investor.

Argentina, Brazil, China, India, Indonesia, Saudi Arabia, South Africa and Turkey.

Albania, Azerbaijan, Bangladesh, Croatia, Georgia, Jamaica, Kenya, Morocco, Nigeria, Peru, Philippines, Senegal, Tunisia and Vietnam.

See the programme on Revenue Enhancement for Developing Economies (REDE). 
It was already understood, however, that foreign direct investment by MNEs posed special problems, since it was hard to determine the appropriate level of profits of the various affiliates (branches or subsidiaries) of a multinational corporate group. A study for the League of Nations in 1932-3 showed that countries used different methods. Some countries (notably Spain) started from the global profits of the MNE as a whole, and apportioned profits to the local entity by applying coefficients appropriate to each business. Most started from each entity's own accounts (especially if it was a separately incorporated subsidiary), although they generally had powers to adjust those accounts. A common approach was to check that the profits taxed in each country were similar to those of independent firms in the same line of business (referred to as empirical methods). Consequently, special provisions were agreed in 1935; these were incorporated into the model tax convention and eventually into bilateral treaties. These gave tax authorities powers to adjust the accounts of related entities, to prevent diversion of profits. In the case of a branch, they allowed an apportionment to it of an appropriate fraction of the company's total profit, and this provision remains today in many treaties, especially of developing countries. ${ }^{4}$

The tax treaty provisions were, however, ambiguous. On the one hand, they gave tax authorities powers to adjust the accounts of related enterprises, or of the permanent establishment (PE) of a foreign corporation, based on the understanding that they are related parties under unified control. On the other hand, the principle to be applied was that the income should reflect what might be expected if the entities were independent.

Consequently, the system as it has developed historically has included both 'unitary' and 'independent entity' elements. It has remained ambivalent between the two. Since that time, the methods which have been developed for allocating the income of multinational corporate groups have in practice been hybrids of the independent entity and the unitary approaches. ${ }^{5}$

Unfortunately, especially in the period of rapid growth of MNEs from the 1960s, many firms began to take advantage of this independent entity principle to reduce their overall tax liabilities, by creating intermediary entities in convenient jurisdictions. Applying the treaty principle literally, each entity should be considered as if it were independent. Intermediary entities, which might exist only on paper, could own assets or perform functions for which operating affiliates would pay royalties, interest or fees deductible from profits, hence reducing taxation at source. Yet these payments could remain untaxed, by channelling them through conduit entities to take advantage of treaty benefits, and on to base affiliates in zerotax countries. Such techniques enabled MNEs to defer taxation on retained earnings, which was a major factor in financing the expansion especially of US-based MNEs.

Today, most MNEs typically consist of hundreds of affiliates, forming complex corporate groups. The shift to the knowledge economy and digitalisation has also facilitated the restructuring of MNE operations around global value chains, which can be tax-driven. This enables the fragmentation of different production functions (research, design, assembly), as well as management and back-office activities. The independent entity principle enables MNEs to attribute only routine levels of profit to entities in high-tax countries, while channelling large revenue for payments for intangibles, finance and fees to low-taxed affiliates. Countries now compete to offer tax advantages to attract the location of entities which perform such high value-adding functions.

The measures adopted by tax authorities to counteract these strategies have continued to remain ambivalent. Some provisions override the fiction of separate entity, such as rules allowing taxation of the undistributed income of a controlled foreign corporation (CFC) as part

This provision allowing formulary apportionment still remains in the article on attribution of profits to a PE in the UN model, and in many actual treaties (Avi-Yonah and Pouga Tinhaga 2014).

As pointed out in IMF (2014). 
of the tax base of its parent. ${ }^{6}$ Others, particularly the rules on transfer pricing, have increasingly emphasised the independent entity principle, while aiming to decide an appropriate allocation of profit by allowing the adjustment of prices of transactions between related entities.

Since the 1980s, many independent commentators have advocated a reform of international tax rules based on treating MNEs as unitary firms. ${ }^{7}$ However, European MNEs strongly objected in the 1970s when US states, notably California, began to apply their formulary apportionment approach on a worldwide basis. ${ }^{8}$ They received high-level political support, and US federal legislation was enacted to substantially restrict state application of formulary apportionment to within the US (Picciotto 1992). In parallel, the introduction of a new approach to transfer pricing by the US at federal level caused conflict at the OECD. This was eventually resolved by agreement to introduce transfer pricing methods using economic analysis to determine appropriate levels of profit, including the profit split method (Durst and Culbertson 2003). Since then, the discreet cloak of ambiguity has remained in place.

As corporate tax strategies have become more sophisticated, the counter-measures have become increasingly inadequate. Governments are clearly at a great disadvantage compared to MNEs, in terms both of resources, and of their ability and incentive to coordinate. The problem of inadequate resources, especially of expertise, is obviously particularly great for poorer countries, but the large OECD countries have also faced increasing administrative strains (Aaron and Slemrod 2004). For example, Kenya has recently benefited from capacity-building from the OECD, establishing a transfer pricing unit of some twenty staff; but the same number of people are employed to advise on transfer pricing in one single private sector firm in Nairobi - KPMG. ${ }^{9}$

As regards coordination, MNEs have even greater advantages since they are centrally directed, although from their perspective they feel threatened by the diversity of national regimes and the potential for conflicts between them. Indeed, such conflicts have increased in recent years, as more countries have strengthened their enforcement of international tax rules, especially on transfer pricing. Many developing countries have introduced such rules only in the past decade or less, but are now activating them. Leading developing countries such as Brazil, China and India have adopted approaches which diverge from those of leading OECD countries, causing friction and conflict. ${ }^{10}$ Coordination between governments

First introduced in the US by the Kennedy administration in 1962, but due to strong opposition from both US MNEs and foreign governments it was limited to CFCs with a specified level of passive income, and located in a low-tax country (Picciotto 1992). Some OECD countries later introduced similar measures, but their effect has been limited due to the conditions applied, which are also relatively easily circumvented. The UK effectively abandoned its CFC rules in 2012, adopting a territorial basis.

$7 \quad$ See particularly Langbein (1986), and for an account and analysis Picciotto (2013). Although unitary taxation is still regarded as anathema among many international tax practitioners, there is a broad consensus among independent academic commentators on this view; for a representative recent sample see Clausing and Avi-Yonah (2007), Vann (2010), Kleinbard (2011b), Fuest et al. (2013) and Devereux and Vella (2014). While these academics agree on the nature of the disease, they differ on the most appropriate cure (some of the options are discussed in Section 5 below). On the other hand, the practitioners involved in the BEPS project preferred to evade an overt diagnosis, in favour of seeking consensus on remedial treatments. However, this consensus in the epistemic community of international practitioners has created an obstacle to informed public debate on the issue. This has been described as 'cognitive regulatory capture' by Langbein (2010), borrowing the term from Willem Buiter in his critique of similar links between central bank policies and the banking community (Buiter 2008).

$8 \quad$ See Section 8 below. An important reason for the protests was that formulary apportionment taxes MNEs on a fraction of their worldwide profits; European firms setting up in California were making low returns there on their large initial investments, which they would find it hard to write off against their profits elsewhere.

$9 \quad$ For further details see the forthcoming ICTD Research Report by Attiya Waris, as well as that on Argentina by Veronica Grondona.

10 KPMG's Global Transfer Pricing Review, published every two years or so, provides information on many countries; for a survey covering Latin America and the Caribbean see CIAT (2013). Accounts of the distinctive approaches of Brazil, China and India were provided in chapter 10 of the UN Practical Manual on Transfer Pricing (2013). Brazil's fixed margin method aims at ease of administration, but is regarded by OECD countries as diverging from their norms. China and India have applied the concept of 'location specific advantages' in ways which also have not been accepted by the OECD. In 2013 conflicts between the competent authorities (responsible for resolving international tax disputes) of India 
through the network of bilateral tax treaties based on the model conventions is flexible, but also slow and clumsy. It was described, perhaps generously, as a 'flawed miracle' by Reuven Avi-Yonah in 1996 (Avi-Yonah 1996: 1304).

The flaws have created an increasing political impetus for stronger coordinated action. This was first taken up by the G7 leaders in 1996, resulting in an initiative through the OECD on Harmful Tax Competition (OECD 1998). This was initially aimed at both the classic low- or zero-tax havens and the increasing number of states offering preferential tax regimes, such as Ireland (which at that time offered ten-year tax holidays to inward investors). However, the OECD initiative was weakened following a change of the US administration, and it refocused on a programme for improving tax information exchange, through bilateral treaties. ${ }^{11}$

A decade and two international financial crises later the political pressure had become stronger. The G8 leaders at their summit in 2013 agreed to establish a new global standard of multilateral and automatic exchange of tax information, as well as transparency of beneficial ownership. In the meantime, the retirement of Jeffrey Owens from the OECD's Centre for Tax Policy and Administration in 2012 provided the opportunity for a new initiative on international tax rules. His successor, Pascal St Amans, quickly started an initially low-key project under the highly technical title of Base Erosion and Profit Shifting (BEPS). This brought together issues which the OECD had already identified, and some on which work had been done. The growing fiscal crises resulting from the financial crash further heightened the political urgency, as well as requiring a broadening of the political base, from the G8 to the G20. The Action Plan on BEPS published by the OECD in July 2013 (OECD 2013) was formally adopted by the G20 leaders, who gave it a strong political mandate, in the St Petersburg Declaration of September 2013 (G20 2013).

\section{The politics and technocracy of the BEPS}

\section{process}

It is important to bear in mind that international tax rules deal with the allocation between states of their rights to tax. ${ }^{12}$ This does not mean that states will necessarily exercise those rights to actually impose tax. Indeed, international tax policy has been dominated by the concern of governments to encourage investment from abroad, and hence to offer tax exemptions or incentives to foreign-owned business. In this respect there can be some divergence between officials in the revenue departments, who are responsible for collecting tax, and those from other branches of government whose concern is to encourage investment, such as ministries of finance, or departments responsible for promotion of business investment, or those dealing with specific sectors such as mining. Responsibility for tax treaties and their negotiation is often a specialism distinct from tax administration, and may come more directly under the the Ministry of Finance rather than the tax administration.

and the US were publicised; the US official complained that his Indian counterpart approached cases from a policy perspective rather than applying the rules, and suspended negotiation of bilateral Advance Pricing Agreements (Parillo and Trivedi 2013). The Indian official was soon replaced, and the US moved to normalise relations (Parillo 2013). India's Central Board of Direct Taxes in January 2015 announced the signature of a Framework Agreement with the US, and a year later reported that over 100 out of some 200 outstanding cases had been resolved. (Government Press Release, available at <http://pib.nic.in/newsite/PrintRelease.aspx?relid=135867>).

11 This was aimed at tax evasion by individuals behind the cloak of bank secrecy. OECD countries began a programme of negotiation of Tax Information Exchange Agreements, mainly with tax havens, and providing for supply of information on request. Critics such as the Tax Justice Network pointed to the inadequacy of this programme, and called for a comprehensive multilateral system of automatic exchange, which was eventually accepted as the goal by the G8 and G20 in 2013.

12 Hence, they establish jurisdictional rules which create what Reuven Avi-Yonah has described as the international law of tax (Avi-Yonah 2004). 
Certainly, since the 1950s, both the drafting and negotiation of tax treaties have been aimed at preventing double taxation, in order to encourage investment. In developing countries in particular, tax treaties are often signed by governments as a political gesture, with little or no involvement of the tax authority. ${ }^{13}$

The BEPS project signals a major redirection of perspective. It resulted from the perception by some officials that international tax rules should also aim to prevent 'double non-taxation'. This was also fuelled by academic articles highlighting the issue of corporate income that is not taxed anywhere, described as stateless (Kleinbard 2011a) or homeless (Wells and Lowell 2011). Dealing with double non-taxation entails stronger coordination of tax rules and of their enforcement, in order to close the loopholes that can be exploited for tax avoidance. A good example is the issue of 'hybrid mismatches'. These occur when a company takes advantage of differences between two treaty partners in their classification of an entity (e.g. whether it is a company or a partnership), or of a financial instrument (whether it is equity or debt). This can enable the firm to take a deduction from gross profits in the source country for a payment which is nevertheless untaxed in the destination country. ${ }^{14}$ The BEPS Action 2 report recommends that source countries should generally deny deductions for such payments, or, if they do not do so, the destination country should treat them as taxable income.

This entails a different view of tax sovereignty than has hitherto prevailed, since it means that the source country's decision on whether to allow a deduction should depend on the tax treatment by the destination country. From a strict tax sovereignty perspective, if the source country has agreed to give the right to tax a payment to the destination country, the latter also has the right to exempt it from tax. Although the issue of hybrids can be explained relatively easily, the technical details are esoteric, and the solutions which have been proposed involve managing complex interactions through elaborate and sophisticated rules. ${ }^{15}$ Developing countries have taken the view that this issue is not a priority for them. More broadly, there may be some reluctance to move towards a reformulation of international tax rules to end double non-taxation if this is seen as restricting source country taxing rights, which is a strong concern for developing countries. Sovereignty is still seen by some developing country representatives as including retaining the right not to tax. ${ }^{16}$

The political mandate for the BEPS project was expressed in broad and simple terms. It called for a reform of international tax rules to ensure that firms could be taxed 'where economic activities occur and value is created' (OECD 2013: 4). However, it also insisted that 'changes to international tax rules must be designed to address the gaps between different countries' tax systems, while still respecting the sovereignty of each country to design its own rules' (G20 2013: 4). These aims are contradictory. As the example of hybrids shows, closing loopholes involving differences between national laws entails closer coordination of both law and policy. The conflict is exacerbated when a government decides

13 Some commentators still continue to emphasise this perspective, see, for example, Lang and Owens (2014); others argue that prevention of double taxation can adequately be ensured through domestic law, while retaining policy flexibility; the lock-in provided by tax treaties might at best be justified as a commitment device to reassure foreign investors, but the evidence on the effect of tax treaties on investment is at best mixed (Brooks and Krever 2015, and, for a case study, Hearson and Kangave 2016)

14 Indeed, structures are available which enable deduction of the same interest twice, or 'double dipping'; these techniques are not new, see Picciotto (1992) chapter 8.3.b, especially p. 205.

15 The final BEPS Action 2 report deals with only the most egregious arrangements, yet runs to some 450 pages (150 of text and 300 of examples). It remains to be seen how many countries will follow the recommendations, and how.

16 This was seen in the discussion in the UN Tax Committee in 2014 of a proposal to include a new provision in its model treaty, along the lines of article 23A.4 adopted by the OECD in 2010, to limit tax exemption in the country of residence if it would result in double non-taxation. The proposal was accepted only subject to inclusion in the Commentary of wording explaining the opposition of some members (UN Committee of Experts in International Tax Matters, Report on $10^{\text {th }}$ Session, doc. E/2014/45-E/C.18/2014/6, paras. 57-8). This resulted from a note of objection submitted by the member from India, who argued that 'developing countries sometimes intentionally enter into treaties including provisions that allow double non-taxation in order to secure their developmental interests' (UN document E/C.18/2014/CRP.16: 3). 
that its tax system must be competitive in order to be business-friendly. This generally signals a willingness to tax corporate profits more lightly, either by offering incentives or by lowering the tax rate. Stronger international tax coordination would inevitably restrict national government's powers to grant many such preferences.

This broad but contradictory mandate from the G20 was entrusted to the tax specialists based at the OECD, who after over two years' exhausting work produced a final package of detailed technical recommendations. ${ }^{17}$ As outlined in the next section, these could give greatly strengthened powers to revenue authorities, depending on the willingness of governments to introduce the necessary legislation, and the determination and ability of tax authorities to enforce those powers. However, they fail to provide clear principles, especially for defining where value is created. Instead, this is left to be dealt with by applying complex methods for making transfer price adjustments based on analysing each company's business model (see next section).

This outcome can be readily understood if we consider the nature of the negotiating process, and the concerns of the various parties involved. Governments sought reforms which could give tax authorities stronger powers to deal with avoidance, while retaining the scope for politicians to design their own rules. A more effective solution, which would entail explicit abandonment of the independent entity principle and treating MNEs as unitary firms, would largely deprive them of this power to tweak national tax rules to try to attract investment by MNES.

The officials directly involved in the process, especially the transfer pricing specialists, generally understand (at least implicitly) that the rules rest on a basic conceptual flaw, resulting in the need for decisions on a case-by-case basis. For them, this ad hoc approach is necessary because it is not possible to reach agreement on general principles for allocating profits based on where economic activities occur and value is created. Those from developed countries, such as the USA, consider that in today's economy value mainly derives from the innovation and research which produce advanced technology and other intangibles, and that this is mostly done in, or directed from, the home countries of MNEs. Those from G20 developing countries with large markets, such as China and India, argue that the market also creates value (as Alfred Marshall said, supply and demand are like scissor blades, both are needed for cutting). But technical specialists consider that it is not their role to resolve these questions in a principled or overt manner, by agreeing factors and weightings for allocating profits. They also consider that political agreement on such criteria would be impossible. Instead, the BEPS reports have produced considerable elaboration of the transfer pricing rules (see next section).

Thus, instead of resolving the central issue by a principled agreement, the problems have been deferred to be decided on an ad hoc basis. The main beneficiaries are the specialists, particularly in transfer pricing, which has grown to be an enormous field of professional practice in the past thirty years. ${ }^{18}$ Their considerable investments in intellectual capital make it hard for most of them to envisage or accept a new approach, and the increased complexity will further enhance the value of their expertise. It will also create an even higher entry barrier for newcomers, particularly from the many developing countries that have introduced transfer pricing regulations only in the last five to ten years. Many aspiring professionals will no doubt relish this challenge, but if the rewards for some individuals are high, so is the social cost of devoting scarce skills to operating a defective system.

In principle, the main hope for pressure for a new approach should come from MNEs themselves. They now face the possibility of strengthened enforcement, including by an

\footnotetext{
17 Available at <http://www.oecd.org/tax/beps-reports.htm>.

18 For a more detailed discussion of the relationships between technicisation and complexity see Picciotto (2015).
} 
increasing number of middle-income and even poorer developing countries; and the ad hoc and subjective nature of many of the rules to be applied will inevitably generate conflicts. Indeed, in addition to conflicts caused by the divergent approaches adopted by Brazil, China and India already mentioned, there has already been a rising tide of disagreements among OECD countries. ${ }^{19}$

Hence, business representatives have pressed for stronger dispute resolution procedures, and the report under BEPS Action 14 proposes measures, especially to strengthen the independence of officials responsible for settling conflicts. Further, some twenty countries have also committed to agreeing to compulsory binding arbitration, long demanded by MNEs. However, these procedures are remote from any concept of independent adjudication: they are conducted entirely in secret, nothing is published even about the existence of a dispute, and only the raw data of numbers of cases by country has been collated by the OECD. This extraordinary level of opacity suggests that the participants could not justify the decisions to a wider public. The suspicion is that the issues are dealt with essentially by bargaining, which the participants naturally wish to conduct in private. Those involved place great faith in their ability to reach agreement based on a common understanding, but this confidence is belied by the growth in conflicts and the increasing time taken to resolve them, even among OECD countries.

Some MNE representatives can now be heard to say, especially in private, that a unitary approach would be preferable, but with the proviso that it must provide certainty in the profit allocation. These voices may grow louder, although only if strengthened enforcement leads to a significant closing down of the scope for minimisation of tax, as well as an increase in inconsistent decisions and conflicts.

\section{Appraisal of the BEPS project outputs}

The BEPS project outputs have not resolved the tensions between the unitary and independent entity elements in the system, but in many ways have sharpened them. The initial BEPS Action Plan stated that 'there is consensus among governments that moving to a system of formulary apportionment of profits is not a viable way forward' (OECD 2013: 14). On the other hand, the general objective of the Action Plan was to achieve reforms which would align rights to tax more closely with real economic activity, to ensure that MNEs could be taxed 'where economic activities take place and value is created' (G20 2013: 4). This implies a shift towards acceptance of the unitary principle. However, the rejection of formulary apportionment seems to have been used as a reason for refusing to resolve the tensions between the independent entity and unitary principles. ${ }^{20}$ As a result, these tensions continue to underlie the proposals, undermining the coherence and potential effectiveness of the package.

Shown in the OECD data on recourse to the mutual agreement procedure for resolving such conflicts, available at <http://www.oecd.org/ctp/dispute/oecd-releases-2014-map-statistics.htm>.

20 This has been pointed out by other commentators. For example, Prof. Michael Devereux, commenting on the aims of the BEPS Action Plan to 'better align rights to tax with economic activity', said: 'I see this as a new principle, this is saying let's tax where there is economic activity or relevant substance. I think if the OECD had gone back and said we need to review these principles and maybe replace them with a new principle which is this, I would have applauded and said this is just what we needed to do. But actually that doesn't seem to be what's happening, what actually seems to be happening is that we are keeping all the old principles and overlaying a new principle on top, which is actually inconsistent with the existing principles, and what do we end up with? Well, we end up with so many different principles we don't know whether we are coming or going.' (Presentation at the conference of the Oxford University Centre for Business Taxation on Tax Competition and BEPS, June 2014, available at

<https://www.youtube.com/watch?v=PLVTrhuQDwA\&list=PLtXf43N26ZidJfK8KN-ffHkfYfFsidivv\&index=1)>. Prof. Edward Kleinbard commented on the BEPS Project: 'I wish them the best, but I think that they've made their lives very hard for themselves by insisting on the arm's length principle as an untouchable sort of axiom' (interview for a blog on the Tax Foundation, 15 May 2015, <http://taxfoundation.org/blog/making-sense-profit-shifting-edward-kleinbard)>. 
This section will give a general overview of the BEPS final reports, especially to show how those proposals that entail a move towards a unitary approach could produce improvements, while those that continue to emphasise independent entity will create further difficulties.

\subsection{Hesitant moves towards a unitary approach}

A number of the proposals in the final BEPS package do entail a shift towards treating MNEs as unitary firms, although this is not made explicit. The major achievement is the formulation of agreed templates for country-by-country reports (CbCRs) and for transfer pricing documentation. These will, for the first time, provide all interested tax authorities with a clear overview of MNEs as a whole, as well as details of the relationships between the different parts. The scheme takes effect as a chapter of the OECD Transfer Pricing Guidelines (OECD 2010), which are applied in practice even by countries which are not OECD members. Hence, although its detailed provisions are only 'soft law', it establishes a global standard which countries can adapt and implement in binding local law. OECD countries have moved quickly to do so, and developing countries should follow suit.

CbCRs will be required only for the largest MNEs (turnover higher than one billion euros), at least until the scheme is reviewed in 2020 . Also, they are supposed to be delivered to the home country tax authorities, and shared with others subject to confidentiality and appropriate use protections. These arrangements create unnecessary obstacles, especially for developing countries. Publication would be a far easier and better solution, and may be the eventual outcome. ${ }^{21}$ Availability of the reports will allow tax authorities to evaluate MNEs as unitary firms, but the scheme insists that they should be used only for risk evaluation, and not as a basis for formulary apportionment. In contrast to the CbCR, the Master File for transfer pricing documentation should be delivered to all relevant tax authorities directly, together with a specific country Local File. Also, these can be required from any firm with a taxable presence in more than one country, and will provide significant detail facilitating audit. All countries should ensure that they have legislation in place which enables their tax authority to obtain this information.

Perhaps unsurprisingly, the BEPS negotiators found it easier to propose unitary approaches to apportionment of costs than of profits. Companies themselves favour apportionment of joint and overhead costs, to ensure that such costs can be deducted somewhere. The BEPS proposals included adoption of a simplified method for pooling and allocating central service costs within a corporate group. ${ }^{22}$ However, many tax administrations are reluctant to allow deductions for such charges, rightly considering that they can be used to undermine the tax base in source countries. Hence, the proposals on this point are limited to low value-adding services, and further work will be done on defining a threshold. The initial proposal envisaged that a profit element should be included, trying to uphold the fiction that this is not an apportionment method. Although this has been weakened in the final report, it still suggests a 5 per cent mark-up, as if this were a contract between independent entities.

An important departure from the independent entity principle came in the proposals on limitation of interest deductions. The initial draft suggested a limit based on apportioning the group's consolidated net costs of interest paid to third parties by the MNE as a whole, in proportion to each affiliate's earnings before interest, tax, depreciation and amortisation (EBITDA). This was explicitly presented as not an arm's length rule. ${ }^{23}$ However, the final

\footnotetext{
21 Momentum for public CbCR is growing, especially in the EU, where it has been proposed as a corporate disclosure rather than as a tax measure.

22 Through revisions to chapter VII of the Transfer Pricing Guidelines (TPGs), in the BEPS Report on Actions 8-10.

23 Discussion draft on Action 4, December 2014, paras. 21-24.
} 
report recommends a fixed cap of between 10-30 per cent of EBITDA, although combined with a group ratio rule, at the taxpayer's option.

The recommendation of a one-size-fits-all fixed cap runs against all the evidence. Data put forward by business groups themselves showed that there are wide variations in the debt ratio between economic sectors and even different firms. A survey for the period 2009-2013 showed that 55-61 per cent of non-financial MNEs had interest expense below 10 per cent of EBITDA, and 78-83 per cent had a ratio below 30 per cent. ${ }^{24} \mathrm{~A}$ fixed cap of 30 per cent is evidently far too high - yet this seems to be the option chosen by OECD states, anxious not to disadvantage their MNEs.

Strong rules on limiting interest deductions could go a long way to ending BEPS. The group ratio rule, based on an apportionment approach, would be a considerable improvement on methods still used by many, especially developing, countries, such as thin capitalisation rules. It would still involve some significant problems, especially the definition of interest. Also, the BEPS project had insufficient time to consider how to limit other types of deduction which erode the source tax base. A more comprehensive approach is suggested by Michael Durst, who has put forward a modified version of the transactional net margin method (Durst 2016), discussed further below.

Ensuring taxation of a group's worldwide profits could be achieved by stronger rules on controlled foreign corporations (CFCs), which also would treat a corporate group as a unitary firm. This also will be discussed in more detail in the next sub-section. However, the final BEPS report contains only recommendations for building blocks. It adopts a cautious approach, remaining ambivalent about whether the main aim is to preserve the tax claims of the parent's home country or those of source jurisdictions, and emphasising the need to balance ensuring that worldwide income is taxed with preserving competitiveness. This is reflected in particular by the report's recommendation that CFC rules should apply only to subsidiaries which are subject to an effective tax rate 'meaningfully lower' than that in the parent's country. Unfortunately, adoption of such weak CFC rules would continue to encourage competition between countries to reduce corporate taxes, and to motivate MNEs to shift profits.

Some measures, although relatively minor, are proposed to combat exploitation of the separate entity principle by fragmenting functions and assigning them to different entities in a group. Tax advisers have for some years been devising schemes for corporate restructuring of supply chain management to reduce liability to tax and other forms of regulation. Such structures enable a company such as Amazon to book sales to an affiliate in Luxembourg which pays low taxes, while separate affiliates in each country dealing with parcel delivery and customer relations declare low levels of profit attributable to those activities. Similarly, Google books its sales of advertising to an affiliate in Ireland, while it has staff employed by another subsidiary in London dealing with marketing, as well as research (Bergin 2013).

The current rules on taxable presence require a permanent establishment (PE), a fixed physical presence for six or twelve months. However, the rules in the OECD model treaty exclude from that definition activities such as warehousing if they are merely preparatory or auxiliary to sales. The proposed changes would remove this exemption if they "constitute complementary functions that are part of a cohesive business operation' carried out by the MNE through other entities in that country (OECD 2015a: 39). Yet, activities such as warehousing would still be considered to be separate from sales. Deeming that it constitutes

24 See data in the survey done by PwC for the Business and Industry Advisory Group (BIAC) of the OECD: Comments received on Public Discussion Draft BEPS Action 4: Interest Deductions and Other Financial Payments, Part 1, p.136, available at <http://www.oecd.org/tax/public-comments-action-4-interest-deductions-other-financial-payments. htm>. The analysis was of public companies in Standard \& Poor's GlobalVantage database, with over 20,000 entries. 
a PE still leaves open the question of what profit should be attributable to it. ${ }^{25}$ Contracts could continue to be booked outside the country, unless the enterprise has an entity or agent there which 'habitually plays a principal role leading to the conclusion' of the contracts (OECD 2015a: 16). It is not clear whether this would affect companies such as Google, since the marketing activities could be organised so that they do not directly involve conclusion of contracts. Indeed, this seems to have been the conclusion of the investigation of Google in the UK, which resulted in a settlement that has been sharply criticised (Public Accounts Committee 2016). Even if the sales contracts were considered to be concluded locally, ${ }^{26}$ that activity would be regarded as separate from operating the search engine, and the activity of managing sales may be regarded as attracting low levels of profit.

\subsection{The need for more radical changes}

A wider approach was opened up by the work of the Task Force on the Digital Economy (TFDE) under Action 1. This could be potentially far-reaching, especially as the TFDE rightly concluded that digitalisation has affected all economic activities to different degrees, so it would be inappropriate to apply different rules to a digital sector ring-fenced from the whole economy. In particular, digitalisation is transforming many service sectors, making it even easier to shift the tax base away from the place of performance, which has long concerned developing countries. However, no conclusion was reached on Action 1, and a further five years was requested for the work of TFDE to continue. In the meantime, all countries are facing major problems posed by taxation not only of internet giants such as Google, but many MNEs, especially in key services sectors, which can use digital technologies to minimise their CIT liability.

The report on Action 1 of the BEPS project recognises that digitalisation means that MNEs have come 'closer to the economist's conception of a single firm operating in a co-ordinated fashion to maximise opportunities in a global economy' (OECD 2015b: para. 232).

Furthermore, it shows that digitalisation undermines the concepts of residence and source on which traditional international tax rules are based, due to two main factors (para. 273). First, firms may make extensive sales of goods and services in a country without the need for any significant physical presence there. Professionals such as lawyers or business advisers can visit clients just for short periods while providing services for much longer, while the delivery of many goods and services can be organised through the internet, though they may be sourced or supported locally. This renders the traditional physical concept of a PE obsolete. Yet the OECD consideration in 1999-2005 of the implications of electronic commerce rejected any significant changes to the PE definition. ${ }^{27}$

Secondly, and more importantly, despite needing a minimal physical presence, firms can now have much closer relations to customers and users. Companies reap enormous value through the systematic collection of data about and from users. Supply relationships are no longer one-way, and users can also contribute considerable value, including content such as comments and reviews. Paradoxically, therefore, firms are more closely bound to their customers, but may not need a significant physical presence in countries where they sell.

\footnotetext{
25 The proposed revision to para. 22 of the Commentary to article 5 states: 'Where, for example, an enterprise of State $\mathrm{R}$ maintains in State $S$ a very large warehouse in which a significant number of employees work for the main purpose of storing and delivering goods owned by the enterprise that the enterprise sells online to customers in State S, paragraph 4 [the exemption] will not apply to that warehouse since the storage and delivery activities that are performed through that warehouse, which represents an important asset and requires a number of employees, constitute an essential part of the enterprise's sale/distribution business and do not have, therefore, a preparatory or auxiliary character'. The issue of attribution of profits to such a PE was left for further work, which entails revisiting the so-called Authorised OECD Approach to article 7.

26 The Google settlement was soon followed by an announcement by Facebook that from April 2016 it would begin to book some of its advertising contracts in the UK - those of large clients with account managers. However, commentators pointed out that this would not result in a major increase in the tax payable.

$27 \quad$ See Annex A of the BEPS Action 1 report.
} 
The report identifies some far-reaching possible reforms to deal with these challenges, but which will require continuing work over the next five years. First would be a new taxable nexus based on 'significant economic presence'. This could result in a greater allocation of the taxable base to the country of sales - for example, if operating a local website were accepted as an activity taking place in the country. The implications of this are even more extensive. It would attribute profits to the entity in the country where the sales take place, although the costs may be borne mainly by affiliates located elsewhere. This makes it essential to adopt a unitary approach, or as the report says it entails a 'substantial rewrite of the rules for attribution of profits' (para. 286). The report canvasses several possibilities, including fractional apportionment, deemed profit methods, a withholding tax on digital transactions, and an equalisation levy.

Digitalisation has also greatly facilitated the fragmentation and restructuring of MNE operations around global value chains, as mentioned in Section 2 above. This has also led to a recognition of the potential role of the profit split method. Although accepted by the OECD since 1995 as within the arm's length principle, this method clearly entails apportionment of the aggregate profits of related entities. However, it is regarded by many as unsatisfactory in practice, unsurprisingly since no work has been done since 1995 to regularise and systematise the approach. Work was begun on it during the BEPS project but not completed, so the final report on the transfer pricing Actions 8-10 includes a chapter outlining the scope of further work on the profit split method, which is expected to take two years. It will cover consideration of the circumstances in which the method is appropriate, specifically including the problems of developing countries in finding suitable comparables, at the request of the G20's Development Working Group. Although the profit split method essentially involves an apportionment methodology, it seems that the intention is still to begin from transactions, and to limit the scope of applicability of the approach.

\subsection{Attribution of profits: transfer pricing and functional analysis}

The greatest reluctance to abandon the independent entity principle is seen when it comes to the allocation of profits. Three of the fifteen BEPS Actions dealt with transfer pricing, and the reports on these have resulted in a substantial rewriting of the OECD Transfer Pricing Guidelines (TPGs), extending them from around 370 to nearly 500 pages. The TPGs are important, because they are applied in practice in countries around the world, and not only by OECD members. ${ }^{28}$ Despite the extensive rewriting of the TPGs, they still stress that the starting point should be the various entities in the MNE group and the transactions between them.

There is nevertheless a significant reorientation of the rules, with a new emphasis on accurately delineating the true nature of these transactions, based on an analysis of the facts and circumstances of each business. This 'requires a broad-based understanding of the industry sector in which the MNE group operates ... including its business strategies, markets, products, its supply chain, and the key functions performed, material assets used,

The OECD considers that its member states are committed to applying the TPGs, including revisions once adopted, and the OECD Council approved the BEPS reports presented in October 2015. In some states they are given statutory status to be used as guidance for tax treaty interpretation, e.g. the UK. Some non-OECD countries, including Nigeria and Tanzania, also have statutory provisions giving the TPGs such status, although along with the UN Manual on Transfer Pricing (UN 2013). Some national courts have relied on the TPGs even without statutory support: for example in Unilever Kenya Ltd (2005), Judge Alnashir Visram rejected transfer price adjustments made by the Kenya Revenue Authority on the grounds that they were contrary to the OECD Guidelines, although the Kenyan legislation at that time made no reference to them. Other countries (e.g. India, US) implement the TPGs through their own rules. Corporate tax advisers generally rely on the TPGs to justify their practices, so that tax authorities generally need to do so as well. Although in most countries the taxpayer in principle has the burden of justifying its accounts, in practice if a structure and pricing scheme have been devised and documented by specialist advisers, the tax authority faces a difficult task to challenge them. 
and important risks assumed'. ${ }^{29}$ On the basis of such an analysis, a tax authority may recharacterise, or in some circumstances even disregard, the ostensible terms of the related party transactions. Once recharacterised, the pricing of the transactions should be evaluated by applying the accepted transfer pricing methods, as far as possible by reference to suitable comparable transactions between independent firms.

The difficulties posed by this procedure should be readily apparent. Tax authorities must carry out individual audits of firms, analysing the firm's group structure and business model, which requires specialist knowledge of each industry. The F-A-R (functions-assets-risk) analysis in the revised TPGs is now elaborated in greater detail especially as regards the functions relating to intangibles, and to risks. A key intention is to ensure that an affiliate that is used simply as a 'cash box', either for owning and receiving income from intangibles, or for group financing, should receive only a minimal return, based on the assumption that it assumes no risks.

However, the logic behind functional analysis is to try to identify the specific functions performed by different affiliates. In practice this is difficult or impossible when it comes to knowledge-based intangibles or risk, both of which are spread through the firm as a whole. Although this flows from the basic theory of the firm, it is also borne out in practice. For example, a submission by BASF, the German-based chemicals firm, explained:

Quality management and controls relating to the risks, functions and assets employed are to a wide extent part of corporate procedures which are generally valid groupwide and are fully integrated in the business processes. The research and development process is managed by electronic systems which track the allocation of projects to specific research centres, the adherence to budgets, the sign-off processes and the registration of IP rights. 'Control' is therefore to a large extent built in to group-wide guidelines and operating systems, and can therefore be performed anywhere as such systems enable a decentralised, collaborative organisation. ${ }^{30}$

Indeed, MNEs pride themselves on being both global and local, able to benefit from their coordination of activities worldwide, while their central management teams may be relatively small.

The revised TPGs place significant emphasis on control functions. In relation to intangibles they identify the specially important functions as 'design and control', 'direction of and establishing priority', and 'management and control' (revised TPGs para. 6.56). Similarly, for identifying the location of risk the key test is the 'capability and authority to control' (para. 1.67).

This control test for the location of key functions clearly favours countries of residence. It is likely that countries where the corporate headquarters, chief financial officer, or main research centre are located will assert that the control over functions such as finance and research is exercised there, even if the firm operates in a decentralised way. Hence, an MNE could employ large numbers of people in research and development activities in affiliates around the world, that could be treated as having only routine research functions, to which relatively low profits would be attributable. ${ }^{31}$ At the same time, the aim to end tax avoidance by attribution of profits to cash-box affiliates may have limited success. A company could relocate a few senior people to carry out control functions in a country which offers low

\footnotetext{
$29 \quad$ New para. 1.34 in chapter 1 section D of the TPGs.

30 In its submission to the Revised Discussion Draft on Transfer Pricing Aspects of Intangibles, September 2013, <http://www.oecd.org/ctp/transfer-pricing/basf-intangibles.pdf $>$.

BASF in its evidence cited in the previous footnote stated that it has 'numerous research hubs, located primarily in Germany, USA, China and India'.
} 
effective tax rates for such activities. Indeed, countries are already competing to attract research hubs by offering low tax rates on structures such as the 'patent box'.

Some revisions have also been made that could strengthen the claims of source countries when conducting this type of functional analysis. This is a response to pressure from nonOECD G20 countries, especially China and India. These revisions deal with 'location advantages', and 'assembled workforce' (revised TPGs Chapter 1, sections D.6 and D.7). However, these provisions are worded very carefully and cautiously. It remains to be seen whether the UN Manual on Transfer Pricing, the 2010 version of which included discussion of these factors especially in the sections from China and India in chapter 10, will be revised to bring it into line with the OECD TPGs.

Following the functional analysis, an appropriate price must be identified for the (recharacterised) transaction. Although the TPGs in principle state that the most appropriate method can be used, it is generally assumed that there should first be a search for suitable comparables - that is, market prices between independent entities. The normal practice is to use databases that are available commercially (though at significant cost). These contain data collected from filings of company accounts, so generally do not include details of transactions, only of company profits by industry sector. So although the methodology stresses the need to start from transaction prices, in practice the focus is on the level of profit.

Data from company filings is, in any case, not available for most developing countries where there is coverage, experience shows that it is hard or impossible to identify suitable comparables. This is especially likely for small economies that may have few significant independent local firms, but transfer pricing specialists in large countries also confirm this. ${ }^{32}$ To deal with this, specialists have developed econometric techniques to use data from elsewhere, adjusting for differences in economic conditions. However, these produce only a range of possible prices, often quite wide (Gonnet et al. 2014).

Indeed, although all the five accepted transfer price methods are described as transactional, only the Comparable Uncontrolled Price method (CUP) directly involves comparing and adjusting transaction prices. The Resale Price Method (RPM) begins from prices of sales to unrelated parties, but reduced by an appropriate gross margin to arrive at a price level used to estimate profits. The Cost Plus Method (CPM) also uses an appropriate margin, but as a mark-up on operating costs. In both cases these calculations are supposed to involve adjustments to the original transfer prices, but clearly the focus is on the profit. Two methods were added in 1995 to these traditional ones, focusing more explicitly on profit, but still described as transactional profit methods. The Transactional Net Margin Method (TNMM) is a refinement of Cost Plus, but is based on the net profit (rather than gross margin), which is calculated in relation to a suitable base, such as costs, sales or assets.

It has become increasingly clear that these methods are inadequate, because they attribute at most a routine profit to operating affiliates. They are described as one-sided methods, since they focus only on the local affiliate, and compare its profits with those of firms conducting activities that could be said to be similar. This ignores the business reality of the advantages of scale and scope, and the synergy resulting from the integrated operations of MNEs. The problem is most evident in relation to intangibles, which benefit the firm as a 
whole, but can be treated as assets, ownership of which can be transferred to an affiliate in a low-tax country. ${ }^{33}$

In response, a fifth transfer pricing method was included in the 1995 TPGs, the profit split method (PSM). This explicitly abandons the focus on transaction prices since it apportions the combined profits, although only those from a series of transactions (hence it is still described as a transactional profit method, like the TNMM). The TPGs recognise the strength of this method especially in relation to 'highly integrated operations', particularly where both parties make 'unique and valuable contributions' (para. 2.109), or to achieve 'a division of the profits from economies of scale or other joint efficiencies' (para. 2.113). The PSM poses technical problems, mainly to deal with the differences between the accounts of the entities whose profits are to be combined. It also requires identification of suitable criteria or 'allocation keys' for apportioning the profits. These questions are also central to formulary apportionment. However, work on the PSM was not completed, and this is one of the key issues which remains outstanding.

This very brief account of the principles and procedures for transfer pricing audits shows their complex and technical nature. It is clearly far easier for large MNEs than for tax authorities to employ consultants skilled in these techniques. If these advisers produce suitable analyses backed by appropriate documentation, it is hard to mount a challenge to the transfer pricing arrangements they design that would be upheld by a court. ${ }^{34}$ There is some evidence that when a country creates a specialist section and strengthens transfer pricing audits, additional tax revenue can result. It is easy to understand that companies are likely to react to the initial threat of enhanced audits by making adjustments to their accounts to pay some more tax. The question however is whether such gains will be sustainable.

More seriously, it is evident that the elaborate and subjective nature of the evaluations involved create considerable potential for conflict, both between tax authorities and firms, and between different tax authorities. Concern about the likelihood of increased conflicts led to pressure for strengthening the dispute settlement procedure, as discussed at the end of the previous section. It seems far preferable to try to devise rules which would be simpler and easier to administer than to rely on dispute resolution procedures to remedy the defects of these contentious and subjective regulations.

\subsection{Conclusions on the BEPS project}

Overall, the BEPS project outputs could provide stronger powers to national tax administrations. However, they also involve considerably increased complexity of the rules to be applied. They include some significant moves towards treating MNEs as unitary firms, but mainly for apportionment of costs. The allocation of profits depends on the transfer pricing rules, which still start from the independent entity principle and transactional analysis. This requires subjective and discretionary evaluations, requiring significant resources of skilled staff.

Evidently the tax experts engaged in the BEPS project could not agree on clear criteria or principles to decide how to allocate profits based on how value is created. Hence, this has been left for case-by-case determination, based on functional analysis. At the same time, this

\footnotetext{
33 The revised chapter VI of the TPGs now states that one-sided methods are generally not reliable for valuing intangibles (para. 6.142).

34 In late 2014, the US Internal Revenue Service (IRS) hired specialist consultants at a cost of \$2 million to assist the IRS audit team in the examination of the transfer pricing arrangements of Microsoft (Gupta 2014). In the UK, HMRC increased its transfer pricing specialists from 65 to 81 between 2012 and 2016; its 6-year investigation of Google's tax affairs involved between 10 and 30 specialists at any one time, and eventually resulted in a settlement agreeing an additional payment of $£ 130$ million covering the period $2005-15$ ( $£ 18$ million for interest, and including a change in the treatment of share-based compensation: see Public Accounts Committee (2016), paras. 4-6).
} 
continues to incentivise MNEs to create complex structures by splitting up functions. Nevertheless this key issue will receive further attention, both in the work on the profit split method and on the digitalised economy. As already mentioned, these issues involve consideration of the MNE as a unitary firm. The remainder of this paper will outline and analyse some of the options that have been put forward for moving towards a unitary approach.

\section{Options for adopting a unitary approach}

The term 'unitary taxation' is often treated as synonymous with formulary apportionment, which is confusing. Several alternative approaches are available that involve treating transnational corporate groups as unitary firms. Indeed, as already discussed above, the existing rules already include unitary elements. Hence, some of these approaches could be compatible with current rules. This section will briefly outline and evaluate some of these unitary taxation methods that do not involve formulary apportionment.

\subsection{Residence-based worldwide taxation (RBWT)}

One is for the adoption of residence-based worldwide taxation (RBWT). This would apply home country tax directly on a current basis on the consolidated worldwide profits of a corporate group, but with a full credit for foreign taxes paid. ${ }^{35}$ This would in effect treat all foreign affiliates on a full-inclusion basis as Controlled Foreign Corporations (CFCs).

RBWT gives the residual right to tax to the firm's home country, but the initial right to the source country. Hence, it can be seen as strengthening source country taxation, by removing the incentive for the MNE to shift profits, since any reduction of source taxation would lead to an equivalent increase of tax in the home country. It also removes the temptation for the source country to offer tax advantages to attract inward investment, for the same reason. However, this can also be seen as an infringement of source country tax rights, if those rights are understood as including a right not to tax. This goes to the heart of the issue of the nature of tax sovereignty raised by the aim of ending double non-taxation, discussed in Section 3 above.

Such provisions could, from a legal perspective, be formulated and implemented unilaterally, without the need for agreement between states, and probably also without alterations to tax treaty rules. Indeed, strengthening of CFC rules was Action 3 in the BEPS project but, as mentioned in the previous section, the final proposals were very weak. In practice, however, its unilateral adoption is difficult in practice, especially for a country with a high corporate tax rate. Since MNEs headquartered there would be subject to that high rate on their worldwide profits, it would create an incentive for them to relocate or 'invert'. This could be counteracted legally, through appropriate residence rules. However, as many have argued, corporate residence is increasingly hard to define. Place of incorporation is obviously ineffective, and place of central management may also be prone to avoidance since it involves identifying where key central management decisions are taken.

Fleming, Peroni and Shay opt for a test of shareholder residency with a 50 per cent threshold, and a rebuttable presumption for place of incorporation (Fleming et al. 2014). This is based on their view that the incidence of the tax is essentially on shareholders. They counter criticism that determining shareholder residency is impractical, by claiming that it is technologically possible, and such information should be increasingly available 'in a post-

35 This has been advocated by a number of US-based commentators, see especially Kleinbard (2011a), Kadet (2013), Fleming et al. (2014) and Avi-Yonah (2016). 
FATCA world'. ${ }^{36}$ They also argue that RBWT is superior to the formulary apportionment variety of unitary taxation, on the grounds that the latter is a territorial system, and hence would affect - they say distort - investment decisions. They concede that, unlike traditional territorial systems, formulary apportionment would not create incentives for artificial profit shifting, but argue that applying the three-factor apportionment formula based on labour, assets and sales would encourage firms to shift assets and employment to low-tax countries. This concern may weigh especially heavily for the US, where the loss of jobs due to outbound investment has left scars. This is discussed in more detail in the next section, in the context of the issues affecting the selection of formula factors in a formulary apportionment system.

Adoption by the US could be feasible as part of a wider reform of corporate taxation, including reducing its current high marginal corporate tax rate of 35 per cent. It is now widely accepted that this is an unacceptable disadvantage compared to for example the UK with a rate of 20 per cent (soon to be 18 per cent), or Ireland at 12.5 per cent. Recognising this, blueprints which have been put forward for reasserting US taxation on a worldwide basis have been coupled with moving to a lower tax rate, which could be politically popular. Although the BEPS proposals were formulated so as not to require significant changes to current US tax statutes, a broader US tax reform is clearly necessary to break up the logjam restricting a more effective and long-term solution. However, this depends on the US domestic political conjuncture, since it raises distributional issues of the relationship between corporate and individual taxation, and indeed the overall level of taxation.

A shift towards RBWT would also be facilitated if a more coordinated approach could be developed, despite the failure to do so in the BEPS project. Notably, the action plan published by the European Commission in June 2015 suggested that EU member states should reform CFC rules jointly (European Commission 2015). Adoption of RBWT by both the US and the EU could make the approach effective, although there should be some coordination, which would be hard to achieve. The BRICS countries are now also the home of large MNEs, and could be potential adopters of RBWT. However, in the present climate, there seems little appetite for such coordination. The draft directive published by the European Commission in January 2016 as part of its anti-tax avoidance package proposed measures to apply some of the BEPS proposals. These included common CFC rules, but aimed only at defined types of passive income, and confined to entities in non-European countries with very low tax rates (a threshold of 40 per cent of the home country rate).

\subsection{A destination-based corporate tax}

Another approach is the concept of a Destination-Based Cash Flow Tax (DBCFT). This has been advocated especially by some economists (Auerbach and Devereux 2013), although others have criticised it (Cui 2015). A pure DBCFT is not a tax on profits, but akin to a Value Added Tax (VAT), except that full and immediate deduction is allowed both of labour costs and other cash expenses including investments. Applied on a destination basis it could therefore be regarded as trade distorting, and hence conflict with world trade rules (Cui 2015).

Nevertheless, from the perspective of international tax rules this approach has the merit that it is in effect a unitary approach, since internal transfers within a corporate group are ignored, and the tax base is both defined and apportioned in terms of sales to third parties (Avi-Yonah 2015). Allocating the corporate tax base according to the location of final consumers may

36 FATCA refers to the US Foreign Account Tax Compliance Act 2010, which requires US taxpayers to report any foreign bank accounts, and foreign financial institutions doing business in the US to report accounts held by taxpayers or foreign entities in which US taxpayers hold a substantial ownership interest. The BEPS Action 3 report on CFC rules discusses how to define a CFC, suggesting a combination of legal and economic control tests; but it does not address the question of how to define the ultimate parent. 
have economic attractions. Notably, corporations could make investment and employment decisions without being affected by the varying tax rates of the jurisdictions where the investments would be made or workers are employed. On the other hand, it raises concerns about the distributional effects on tax revenue for countries with small consumer markets.

It also raises considerable practical problems. First, it requires identification of the location of customers, which is difficult in the era of electronic commerce. However, some solutions are being developed in relation to the shift of VAT to a destination basis, by both the EU and the OECD. The report on BEPS Action 1 suggests the possibility of taxing sales transactions, enforced through intermediaries such as banks. This would require foreign firms to register and maintain identifiable accounts, payments into which would be taxed. This mechanism could be used either for a sales transaction tax, or as a withholding tax on sales credited against a corporate income tax liability. ${ }^{37} \mathrm{~A}$ stronger objection is that a high proportion of exports consists of sales of intermediate goods to businesses, and not finished products to final consumers. This could encourage the location of assembly industries in countries with low CIT rates, to reduce the cost of inputs.

Another major problem is that, since its tax base is based entirely on sales, the DBCFT brings into sharp relief the problem that taxing rights could be allocated to countries where a company has little or no physical presence. To deal with this, Devereux and de la Feria (2014) suggest a clearing house system, modelled on the one-stop-shop being trialled in the EU, to enable the VAT to move to a destination basis. This is clearly more than just a practical issue. It would entail considerable cooperation among states, in effect a joint system of collection and enforcement of corporate taxes, with a netting-out procedure, including an element for the costs of collection (Devereux and de la Feria 2014). In view of the experience to date of attempting to reach agreement between states, this seems to be an extremely ambitious undertaking.

\subsection{Other alternatives}

A more pragmatic way forward could be to sacrifice some purity for achieving simplicity in allocating the consolidated tax base of a unitary enterprise. This may be especially important for developing countries, which would experience considerable difficulty in applying complex methods requiring considerable skill and judgment. It is for these reasons that Brazil adopted its distinctive system based on legislatively fixed margins, which seems to have been successful - at least in ensuring ease of administration. By removing the need for subjective evaluation by tax officials, it greatly reduces administrative costs, removes the temptation for corruption, and virtually eliminates litigation. However, setting profit margins by broad industry sector is a very broad-brush approach.

With such aims in mind, Michael Durst puts forward a proposal for a modified version of the TNMM (Durst 2016). This would avoid the need for a detailed audit based on functional analysis and attempting to identify comparable independent firms, by simply establishing a benchmark for the local affiliate's profitability. This would require the local affiliate to earn a profit margin in proportion to that of the corporate group as a whole. The benchmark he suggests is 25 per cent of the group's earnings before tax (Durst 2016), based on experience of attempting to apply the TNMM to a wide range of distributors, manufacturers and service providers. The fraction is chosen to arrive at a profit allocation which could be acceptable to both the revenue authority and the taxpayer. It would generally prevent the very low requirements of income that under current practice tend to be ascribed to 'risk-stripped' subsidiaries in the course of BEPS planning. The suggested method would require a minimum level of income, consistent with group-wide profitability, even after payment of interest, thereby limiting base erosion through the use of related-party loans, as well as other

37 For a contrary view, see Cui (2015) (who, however, does not seem to have taken account of these proposals). 
deductions of payments to related parties. Such a provision could be applied as a 'safe harbour', although to be effective it should not be optional for taxpayers.

\section{Unitary taxation with formulary apportionment}

Despite the promise of a unitary approach in controlling base erosion and profit shifting, it is plain that countries, and international organisations advising and assisting them, would need to address a number of important and as yet unresolved technical challenges, especially if a full system of unitary taxation with formulary apportionment is to be applied effectively in the international sphere. Such a system would require: (i) combined reporting, based on a template for both worldwide consolidated accounts and country-by-country data on revenue, physical assets, employees and sales; (ii) the selection of appropriate factors for apportioning the profits; and (iii) a conflict resolution procedure. In this section and the next we will discuss the issues involved in the first two of these, drawing on and referring to the papers resulting from this research programme.

The aim of a combined report is to establish the appropriate tax base of the corporate group concerned, and provide the data necessary for apportioning that base among the relevant countries in which it has a taxable business presence. The first issue here is the delimitation of the relevant tax base, and next is the method for its definition.

\subsection{The taxable nexus: unitary business or unitary enterprise?}

Two approaches to this issue can be discerned (Siu et al. 2014; Hellerstein 2014). The first is that of the US state system, which focuses on the business activities. This has two corollaries. It means that the income to be apportioned is only that which derives from the socalled unitary business, and also that a state may claim to tax an apportioned share of such business earned by a corporation even if it has no affiliate or branch in the state. The limitation of the tax base to the unitary business, which entails an activity-by-activity definition of the tax base, derives from US constitutional considerations. The resulting need to delineate the boundaries of what constitutes each unitary business in which the taxpayer engages has greatly complicated practice in the United States.

It would seem far more promising administratively to apply formulary apportionment to the entire combined income of a commonly controlled group that performs business in the taxing state (combined-income apportionment). This avoids the often tricky debates over what constitutes a unitary business that have bedevilled the US state system. The distinction between combined-income and activity-by-activity apportionment is addressed in Durst's evaluation of formulary apportionment. He argues in favour of a combined income principle, while conceding that it could not be applied under current tax treaty rules (Durst 2015). The paper by Sadiq supports this for the finance sector, and also discusses the ownership and control criteria for definition of the group, which may cause problems in the finance sector if they are too narrow (Sadiq 2014).

However, it would also seem necessary to treat full inclusion as a presumption, and provide tax authorities with anti-avoidance powers to exclude activities which may have been brought within a corporate group to seek a tax advantage, by 'gaming' the apportionment formulas applicable. The whole-income approach also runs counter to the principles of attribution of profits to a PE developed by OECD countries, culminating in the authorised OECD approach adopted in 2010 by a majority of OECD countries. However, this has been generally rejected by developing countries, and has so far been incorporated into only a few actual treaties. 
Indeed, the issue of attribution of profits to a PE has been reopened by the changes to the PE definition agreed in BEPS Action 7, and remains to be resolved in further work. These tax treaty questions are discussed by Avi-Yonah and Pouga Tinhaga (2014).

The enterprise whole-income approach to tax base delineation also points to the need to reconsider the current definition of PE for establishing a taxable nexus. This is clearly now urgent, and indeed has been recognised in the BEPS project in the final report under Action 1 on the tax consequences of the digital economy, discussed in Section 4 above. One of the options it identifies is a new criterion for taxable nexus based on significant economic presence. However, as the report points out, current rules on attribution of income would not be appropriate for a wider concept of a PE. Moving towards a modernised concept of PE for the new economy would be much easier under a unitary approach, which would either apportion joint costs proportionately against gross income, or simply apportion net income.

\subsection{Calculation of the tax base: tax and accounting rules}

Probably the greatest technical challenge of formulary apportionment is posed by the divergence between financial and tax accounting. A company's books and records, and the accounts based on them, are necessarily the starting point. However, as shown in the paper by Murphy and Sikka (2014), tax authorities around the world generally require financial accounts to be restated for tax purposes. As Murphy and Sikka explain, this divergence has become greater in recent years, as financial accounting standards have increasingly focused on the needs of financial markets, and hence a primary concern with forecasting of future cash flows. This results, notably, in asset valuations based on market prices rather than actual historical costs, and recognition of unrealised rather than received income. On the other hand, MNEs already prepare group accounts based on financial reporting standards, including criteria for defining the group based on control, and rules for consolidation. There has also been considerable international convergence of financial reporting, especially through the International Financial Reporting Standards, although Murphy and Sikka point out that some significant national differences remain, both in the formal rules and in local culture and practices. Perhaps for this reason, as they demonstrate, the CCCTB does not begin from the consolidated financial accounts of the relevant group of companies, but from the individual national accounts of the various affiliates of the group, which are then required to be adjusted to the tax standards stated in the CCCTB, and only then aggregated.

However, the natural starting point for an international system of combined-income unitary taxation should be the group's global consolidated accounts. These would need to be converted to tax accounting standards, since few tax administrations would be willing to accept financial accounts as a tax base. Conversion to national tax accounting rules of a variety of countries would involve complications, but Michael Durst suggests that this would mainly entail an exercise of programming the accounting databases already used by MNEs (Durst 2015). In practical terms, even with a high degree of difference among countries' tax accounting rules, available technology should permit the accomplishment of the necessary accounting conversions, especially if statutes allow taxpayers reasonable scope for approximation in converting book into taxable income.

However, it would be preferable if there could be international convergence or harmonisation of tax base definitions. The analysis of Murphy and Sikka suggests that the standards developed for the EU's CCCTB show that an acceptable consensus can relatively easily be reached on a substantial proportion of the relevant book and tax accounting standards, using a transaction-based approach to the recognition of revenue and deductible costs, and recognising only realised profits, with its associated capital maintenance concept of maintaining financial capital. Significant differences remain, of course, essentially in relation to allowances for capital expenditure and certain investments such as research and development. They suggest that these could simply be left to individual states. The corollary, 
they point out, is that the apportionment formula should not include assets, which in any case involve difficult valuation issues.

\section{The choice of an apportionment formula}

The basic underpinning of a unitary approach is the understanding that the profits generated by an integrated firm result from the synergy of its activities as whole. Hence, this approach does not attempt to attribute particular parts of the profit to specific affiliates or entities within it. Instead, the aim is to apportion the profits, on the basis of factors which reflect the firm's real activity in each country. This ensures a direct link between a company's actual business presence in a country and its contribution through taxes towards the collective services and infrastructure that facilitate that business.

Historically, especially in the United States, state apportionment formulas have applied three factors: employee payroll costs, sales and physical assets, equally weighted under the 'Massachusetts' formula. For the CCCTB a similar three-factor formula has been proposed, but with the employee factor equally weighted between payroll costs and headcount.

It is often argued that it would be impossible to reach political agreement on the apportionment formula, and that without such agreement there would be an unacceptable level of double taxation. A second argument is that unitary taxation would not end tax competition between states, or tax planning by companies, but shift them onto new ground. However, these overlook the point that, in choosing a suitable formula, states would need to take into account interacting factors: not only the tax revenue it would produce, but also the effects on inward investment.

\subsection{The formula and tax competition for investment}

Countries will, of course, evaluate the likely effect on their ability to attract foreign direct investment of both the formula they apply and their corporate tax rate, and firms would obviously consider these same factors in their location decisions. Hence, a state would need to balance the effects of the formula on tax revenue with those on investment. The incentive effects on both national tax policies and corporate strategies could therefore be mutually supportive, and potentially benign. In particular, firms would have an incentive to shift labourintensive activities away from countries which emphasise labour in the apportionment factors. As a corollary, countries would have to consider the effect of emphasising the labour factor not only on tax revenue, but also on investment. Indeed, in practice US states have perceived the inclusion of employee compensation and property factors as discouraging companies from locating employment and physical plant in their jurisdictions, and have moved towards a higher weighting for sales.

Unlike the situation under current international tax rules, these decisions would concern real and not paper activities. This has important implications. It means that this revenueinvestment trade-off would create a basis for convergence or agreement between states in the choice of apportionment factors, and that this choice is not a zero-sum game. States with a labour-intensive economy would not necessarily choose a high labour weighting in the apportionment formula, for fear of driving away investment, and discouraging investment to improve productivity. Hence, even in the absence of agreement on the apportionment formula, double taxation is unlikely to result. Indeed, there is perhaps a bigger danger of double non-taxation, unless states can learn from experience and agree to coordinate.

This can be seen from the experience in the United States. There, as shown in Clausing's paper, whereas 80 per cent of states used an equal-weighted three-factor formula in 1986, 
this had fallen to 17 per cent by 2012 (Clausing 2014). States instead moved to increase the weight on the sales factor, with 30 per cent of states in 2012 going so far as to use a singlesales factor formula. The reasoning has been that this would encourage investment for production, and hence increase employment in the state. Clausing shows that, although increasing the sales factor may attract investment in the short run, it ceases to have a significant effect over a longer period, presumably as competitor states adopt similar policies. It will be interesting to observe whether this experience will stop, or perhaps even reverse, the trend towards the sales factor.

More serious is the trend to an overall reduction of tax revenue. Adoption of a single sales factor could mean that the tax base may be apportioned to states where the company has no taxable presence, simply exporting to independent customers. However, states have dealt with this problem in two ways, discussed by Siu et al. (2014). First, a state adopting the sales weighting can couple it with a 'throw-back' rule under which, if profits are not taxable in the destination state, the sales are attributed to the source state. Around half of US states which moved to a sales-only factor adopted a throw-back rule, and the proposed CCCTB also included one. Secondly, US states have adopted wider taxable presence rules, although federal legislation and court decisions require a more significant presence than simply solicitation of sales.

Adoption of a wider taxable presence standard in international tax would indeed be desirable, especially in response to the digitalisation of economic activity, as pointed out in Section 4 above. The taxable nexus criteria could be extended beyond the physical requirements for a $\mathrm{PE}$ in current tax rules, by adoption of a concept of Significant Economic Presence, as suggested in the BEPS Action 1 report. This could include, for example, selling through a website in the local language, using local agents for activities such as order fulfilment, and selling locally-sourced products or services. This should ensure that virtually all the profits of MNEs would be taxable somewhere, without extending the net too widely to include the many small and medium enterprises with foreign sales from a purely home base. Wherever they have significant sales, MNEs generally require some business presence, such as local assembly, sourcing of inputs, distribution, packaging, marketing, and other close engagement with customers.

Nevertheless, a drift toward sales-only formulas may constitute a problem under formulary apportionment, especially since much foreign investment in developing countries involves production or extraction for export without significant local sales. Nevertheless, even salesbased apportionment could provide developing countries much better revenue results than current arm's-length transfer pricing rules. It should also be borne in mind that developing countries too are significant importers of goods, and especially services, from multinationals, often with little or no local value added, so that such activities contribute little or nothing to the tax base under current rules. Thus, the net effect of a sales basis for apportionment for them would depend on the balance of exports to imports by MNEs, taking account also of whether MNEs responsible for imports have a taxable presence in the country. These countries should apply the destination basis also to sales of services, provided the services supplier has a significant business presence. Developing countries have been disadvantaged by the shift towards a services economy, due to the difficulty of taxing profits of foreign service suppliers under current tax rules, even though such a claim to tax can be justified by the importance for services of close relations with clients. On the other hand, they would be justified in applying a source basis for sales of minerals and hydrocarbons, since these are anyway heavily taxed at and after processing in the countries of consumption.

Another advantage is that emphasising the sales factor removes the temptation for states to reduce corporate tax rates. As Clausing (2014) shows, US state tax rates have remained stable even as there has been a shift towards the sales factor in apportionment. Thus, any reduction in the tax base resulting from a shift towards the sales factor could be 
compensated for by increasing the tax rate. Finally, formulary apportionment based solely on sales by destination would be similar to the DBCFT discussed in Section 5 above, although it would apply to profits.

\subsection{Effects of the formula on tax revenue}

Probably the main political obstacle to adoption of unitary taxation is that states fear the possible effects on redistribution of the tax base. This fear is probably all the more potent because the effects are very difficult or impossible to quantify with any accuracy. Firstly, such analyses are likely to be static, since it would be hard or impossible for a model to take account of the possible dynamic effects on investment, which were discussed in the last subsection. Secondly, there are significant problems of lack of data, especially relating to developing countries. The paper by Cobham and Loretz (2014) shows the severe limitations in this respect of the main large commercially-available dataset of corporate accounts (Orbis from Bureau van Dijk). The data is collated from filings of corporate financial accounts, so not only is there no data at all from most developing countries, Cobham and Loretz were obliged to use turnover as a proxy for the sales apportionment factor instead of sales by destination. ${ }^{38}$ Hence, as is generally the case, quantitative findings must be used with great care, and in conjunction with qualitative analyses.

A primary consideration is the likely effect on the overall corporate tax base. Firstly, using consolidated accounts as the starting point would mean some overall reduction in the tax base, since this would allow international offsetting of losses. ${ }^{39}$ This indeed is a significant attraction for MNEs, seen, for example, in the support from many of them for the CCCTB proposal. The paper by Cobham and Loretz (2014) estimates this reduction at 12 per cent overall, with some significant differences between countries. As they point out, international loss-offsetting would reduce the disincentive to make risky investments in new countries. The numbers should be treated with caution, particularly as they are based on financial accounts, and as discussed above the recognition of profits is very different under tax rules.

Nevertheless, there would undoubtedly be such an effect.

This will, of course, be counterbalanced by the main intended effect of unitary taxation, which is to counteract the artificial attribution of profits to low-tax countries. Cobham and Loretz show that this also has a significant impact on the overall tax base, under any apportionment formula, as more profits are attributed to countries with higher tax rates. They estimate that, overall, under almost any formula there would be a slightly positive effect on overall tax revenue, cancelling out the overall reduction from international offsetting of losses. The exception is their finding that apportionment based on number of employees redistributed revenue to lower-income countries that also had lower tax rates (in their sample, in eastern Europe). This had the effect of slightly lowering overall revenue. However, this assumes that those countries would maintain the same tax preferences and rates as at present, which is unlikely to be the case. Importantly, also, their data covers countries with preferential tax regimes, such as Ireland, Luxembourg and The Netherlands, but not the outright tax havens: notably, their sample includes only 186 affiliates in Caribbean countries. The overall impact of formulary apportionment in reducing BEPS is highly likely to result in a very significant increase in the overall tax base. Although the report on BEPS Action 11 found the losses from BEPS hard to measure, it gave estimates of between 4-10 per cent of the global CIT tax base - that is, between $\$ 100$ billion and $\$ 240$ billion. This would generate higher overall corporate tax revenue, which could be used to reduce tax rates.

\footnotetext{
$38 \quad$ The same problem was faced by the illustrative calculations attempted by the IMF (IMF 2014); the text emphasises the big difference in the redistributional effects if payroll costs are used as against headcount for the labour factor, but perhaps even more significant is the redistribution away from 'conduit' countries under any apportionment formula. Under the independent entity principle losses incurred by one affiliate, for example in the early years of a green-field investment, could not normally be off-set against profits in another jurisdiction.
} 
Aside from the expected and intended redistribution of artificially-booked profits, different apportionment factors would, unsurprisingly, result in some redistribution between countries. The calculations by Cobham and Loretz suggest that the physical assets factor would tend to benefit low-income countries, and the turnover factor high-income countries; in the case of employment, a factor based on number of employees would benefit low-income countries, but this would be much less on the basis of payroll costs (to the extent that data is available). This clearly supports a balanced formula using both production factors (assets and employees) and consumption factors (sales by destination), along the lines of the traditional US formula. This was adapted in the proposed CCCTB to split the employment factor 50:50 between employee numbers and payroll costs, which seems appropriate to use internationally in view of large differences in wage levels. Another means of adjusting for wage disparities is to compare payroll data using purchasing power parity.

Some suggest that the physical asset factor should be dropped, since it is now much less relevant; also, as pointed out above, it may be difficult to quantify accurately. This would suggest a two-factor formula, balancing sales by destination and employees (equally weighted by headcount and payroll costs). The argument that intangible assets should be included misunderstands the fundamental argument for a unitary approach. As already stressed, this rejects the view that profits can be attributed to particular assets or activities, but treats them as generated by the operations of the firm as a whole, and apportions them according to its real presence in each country. The high value added by, for example, research and development teams, should be reflected in the employee factor, and apportioned to where the people are physically based. Attributing the profits to the intangible assets is both inappropriate and a recipe for BEPS.

Finally, the possibility that different competitive concerns might lead countries to adopt different formulas should not be seen as a prohibitive concern. Diverging apportionment formulas should pose no greater problem for international investors than, for example, differences among countries in tax rates or in depreciation allowances, provided that the investor knows each country's formula in advance and is able to calculate its effective tax rate in each country (Durst 2015). Today, under arm's-length pricing rules, the investor has no reliable means of predicting its effective rates. Under apportionment formulas set in advance, however, the investor will have greater certainty than is available under arm'slength rules, even if different countries' formulas differ. It would nevertheless obviously be desirable if formulas could be aligned.

\section{Could formulary apportionment be adopted regionally?}

Federal or confederal states, most notably the United States, Canada and Switzerland, have been using formulary apportionment for the division of income among jurisdictions for many years (Siu et al. 2014). In addition, a proposal for a regional system, the Common Consolidated Corporate Tax Base (CCCTB) has been under development within the European Union for over a decade. These systems, however, are limited in their effect: they govern only apportionment of income within the particular federal union, or parts of it, that have adopted them, but they do not govern apportionment of income between the federal unions and other tax jurisdictions around the world. Indeed, since the conflicts which arose in the 1980s over the application of formulary apportionment by US states, especially California, on a worldwide basis (Picciotto 1992), US states have been obliged to offer a 'water's edge' basis of assessment, limited to the USA. Not surprisingly, the EU's CCCTB is also scrupulous in insisting that the normal separate entity/arm's length principle should 
apply outside the group of states which might adopt a CCCTB. The existing regional systems, therefore, while providing important lessons concerning the best technical rules for structuring unitary tax systems, cannot be seen as providing direct models for unitary taxation either for an international tax regime, or indeed for other regions.

Several considerations suggest that regional adoptions of unitary taxation, for use within regional groups as well as between those groups and countries elsewhere in the world, may be especially useful for groups of developing countries. Firstly, because developing countries depend relatively more heavily on international corporate tax revenue than wealthier countries, developing countries have the greatest incentive to ensure that international tax rules provide effective protection against base erosion. Secondly, regional adoption can permit pooling of resources to meet the compliance and enforcement demands posed by unitary taxation, perhaps by creating centralised tax inspection resources. Thirdly, regional adoption could help to mitigate pressures of tax competition among neighbouring countries, which in the absence of a common, regional approach might tend excessively toward a sales basis for apportionment, as has occurred among the US states.

The survey in the paper by Siu et al. (2014) suggests that regional groupings vary widely in their approach to harmonisation of direct taxation of corporate profits. While this is not on any agenda in Latin America or Asia, the East African Community (EAC) seems to be much more willing to move in this direction. This is perhaps due to the previous regional experience of the East African Federation, which disintegrated to a great extent because of the tensions caused by the unequal benefits resulting from providing foreign-owned firms with access to the regional market. Also, unlike even the EU, direct tax harmonisation is included among the mechanisms envisaged for building the EAC. Devising a possible regional system here seems a fruitful avenue for practical investigation.

Some point to the slow progress by the EU on the CCCTB as evidence of the insuperable difficulties of adopting unitary taxation. This must be evaluated in relative terms. Even in areas which are less contentious than direct taxation, such as harmonisation of product standards and regulation of services, progress has often been slow, and marked by shifts to new approaches. In the tax field also, harmonisation of the Value Added Tax, accepted as necessary for a single market, has been fraught with difficulties, and is only now moving to a destination basis, finally accepted as more suitable for an integrated market. In this perspective, the CCCTB can be said to have made remarkable progress, especially since the fiscal crisis. Indeed, following completion of the OECD's BEPS project, the Action Plan published by the European Commission in June 2015 once again identified the CCCTB as the only holistic solution, and proposes a relaunching of the proposal. It also envisaged parallel work on joint implementation of the BEPS project proposals, significantly including the possibility of common CFC rules. ${ }^{40}$ This would be important, since the tax base to be apportioned internally among participants in a CCCTB would be defined by application of its external international tax rules.

Hence, progress on the CCCTB and on BEPS are not opposed, but complementary. Some may indeed argue that a CCCTB is insufficiently ambitious, and that a truly integrated regional grouping (probably consisting only of core EU states) should move to a single corporate income tax. Here we have confined ourselves to examining the experience of existing systems, and the proposals which have emerged from such experiences.

\footnotetext{
40 A proposed Anti-Tax-Avoidance Directive was published on 28 January 2016 (COM(2016) 26 final). However, as
} mentioned in Section 5 above, its proposed CFC rules are very weak. 


\section{Conclusions}

Unitary taxation with formulary apportionment is clearly not a panacea. It certainly entails technical challenges and faces political difficulties. Our claim is simply that adoption of this approach is the only way to establish an effective internationally-coordinated system for taxation of MNEs. We have outlined above the flaws which lead to the dysfunctionality of the present system, and the reasons for thinking that a unitary approach would be superior. It is surprising that despite widespread support for these views, there has been very little serious research on the issue: to the contrary, even suggestions that it should be seriously studied have met with hostility. We hope that the projects in this programme have begun to fill this gap, and may persuade both policymakers and researchers of the need for more serious evaluation of alternatives to the long-troubled arm's-length paradigm.

Such research should, of course, be practically grounded, and run alongside the reform efforts stimulated by the BEPS project, as well as debates about other alternatives which are also based on the unitary principle (discussed in Section 5 above). Of these, we see an overlap and interaction between RBWT and formulary apportionment, despite the assertion by some proponents of the former that they are opposed, since they castigate formulary apportionment as a territorial system. RBWT would perhaps require less technical preparation, since it could build on existing concepts in CFC regimes or national consolidation regimes. However, the key factors now seem to be political. Although RBWT would seem easier to introduce unilaterally, in practice any country seriously considering the option would be placed under great pressure by threats of corporate relocations or 'inversions'. Such threats could be deflected by strong anti-inversion rules, preferably accompanied by concerted action. Such coordination might be possible especially between the US and the EU, which might consider common full-inclusion CFC rules in conjunction with the introduction of a CCCTB. However, this is speculative.

Developing countries will need substantial guidance in developing adequately functioning systems to replace their current regimes. Intergovernmental organisations with the necessary resources should strongly consider initiating a serious, extended and open-minded exploration of the technical challenges of implementing systems of unitary taxation based on formulary apportionment, perhaps initially among regional groups of developing countries which see a particularly strong need to protect their corporate tax bases for the foreseeable future.

Serious efforts towards the implementation of formulary rules should nevertheless be paralleled by the introduction, particularly in developing countries, of more limited measures to inhibit base erosion, such as some of the measures recommended by the OECD's work on BEPS. Historical experience, however, suggests a substantial likelihood that measures short of formulary apportionment will fail over time to curtail base erosion effectively. These countries should consider carefully the possibility that a formulary approach can provide protection to fiscal systems that cannot be achieved by other available means. Building on the insights that already have been developed through the recent analyses of base erosion by the OECD and others, it is suggested that the international economic community, including those with special responsibility for economic development, establish a process of devoting the resources necessary to conduct a comprehensive, open-minded and expert review of the potential that explicitly formulary rules might contribute to a sound system of international taxation, especially for the benefit of developing countries that must continue to rely relatively heavily on revenue from corporate taxation.

Finally, we should close with a reminder that, as important as reform of international taxation may be, such reforms have much wider ramifications. The tax avoidance techniques generated by the flaws in the system as it developed historically have been major factors in 
the creation of the offshore system of tax havens and secrecy jurisdictions. Although its use by MNEs appears for the most part to be legal, the same techniques and facilities have come to be used or abused for a much wider variety of much more dubious, illegal and dangerous practices. These range from avoidance of other types of regulation, from shipping safety standards and banking regulation to facilitation of money laundering and terrorist financing. Removing the incentives for our largest and most important corporations to use plainly illogical tax avoidance arrangements would be an enormous step towards restoring integrity to the international system for regulating trade and investment. 


\section{References}

Aaron, H. and Slemrod, J. (2004) The crisis in tax administration, Washington DC: Brookings Institution Press

Auerbach, A. and Devereux, M. (2013) Consumption and Cash-Flow Taxes in an International Setting, NBER Working Paper No. 19579, available at $<$ http://www.nber.org/papers/w19579>

Avi-Yonah, R. (2016) 'Hanging Together: A Multilateral Approach to Taxing Multinationals', in T. Pogge and K. Mehta (eds), Global Tax Fairness, Oxford University Press

Avi-Yonah, R. (2015) The Case for a Destination-Based Corporate Tax, available at SSRN: <http://dx.doi.org/10.2139/ssrn.2634391>

Avi-Yonah, R. (2004) International Tax as International Law, available at $<$ http://ssrn.com/abstract=516382>

Avi-Yonah R. (1996) 'The structure of international taxation: A proposal for simplification', Texas Law Review 74: 1301-1359

Avi-Yonah, R. and Pouga Tinhaga, Z. (2014) Unitary Taxation and International Tax Rules, ICTD Working Paper 26, Brighton: International Centre for Tax and Development

Bergin, T. (2013) 'Special Report - How Google UK clouds its tax liabilities', $1^{\text {st }}$ May, Reuters

Brooks, K. and Krever, R. (2015) 'The Troubling Role of Tax Treaties', in M. Geerten, M. Michielse and V. Thuronyi (eds) Tax Design Issues Worldwide, Alphen aan den Rijn: Kluwer Law International, available at <http://papers.ssrn.com/sol3/papers.cfm?abstract_id=2639064>

Buiter, W. (2008) Central banks and financial crises, Discussion paper 619, LSE Financial Markets Group

CIAT (2013) El Control de la Manipulación de los Precios de Transferencia en América Latina y el Caribe/The Control of Transfer Pricing Manipulation in Latin America and the Caribbean,

Clausing, K. (2015) The Effect of Profit Shifting on the Corporate Tax Base in the United States and Beyond, available at SSRN: <http://ssrn.com/abstract=2685442> or $<$ http://dx.doi.org/10.2139/ssrn.2685442>

Clausing, K. (2014) Lessons for International Tax Reform from the US State Experience under Formulary Apportionment, ICTD Research Report 2, Brighton: International Centre for Tax and Development

Clausing, K. and Avi-Yonah, R. (2007) Reforming Corporate Taxation in a Global Economy: A Proposal to Adopt Formulary Apportionment, Washington: Brookings Institution

Cobham, A. and Loretz, S. (2014) International Distribution of the Corporate Tax Base: Implications of Different Apportionment Factors under Unitary Taxation, ICTD Working Paper 27, Brighton: International Centre for Tax and Development 
Crivelli, E., De Mooij, R. and Keen, M. (2015) Base Erosion, Profit Shifting and Developing Countries, IMF Working Paper WP/15/118

Cui, W. (2015) Destination-Based Cash-Flow Tax: A Critical Appraisal, available at SSRN: $<$ http://dx.doi.org/10.2139/ssrn.2614780>

Devereux, M. and Feria, R. de la (2014) Designing and Implementing a Destination-Based Corporate Tax, OUCBT Working Paper 14/07

Devereux, M. and Vella, J. (2014) Are we heading towards a corporate tax system fit for the 21st century?, OUCBT WP 14/2014, Oxford University Centre for Business Taxation

Durst, M. (2016) Developing Country Revenue Mobilisation: A Proposal to Modify the 'Transactional Net Margin' Transfer Pricing Method, ICTD Working Paper 44, Brighton: International Centre for Tax and Development

Durst, M. (2015) The Tax Policy Outlook for Developing Countries: Reflections on International Formulary Apportionment, ICTD Working Paper 32, Brighton: International Centre for Tax and Development

Durst, M. and Culbertson, R. (2003) 'Clearing Away the Sand; Retrospective Methods and Prospective Documentation in Transfer Pricing Today', NYU Tax Law Review 57: 37136

European Commission (2015) A Fair and Efficient Corporate Tax System in the European Union: 5 Key Areas for Action, European Commission

Fleming, J., Peroni, R. and Shay, S. (2014) 'Formulary Apportionment in the U.S. International Income Tax System: Putting Lipstick on a Pig', Michigan Journal International Law 36: 1-57

Fuest, C., Spengel, C., Finke, K., Heckemeyer, J. and Nusser, H. (2013) 'Profit Shifting and "Aggressive" Tax Planning by Multinational Firms: Issues and Options for Reform', World Tax Journal 5: 307-324

G20 (2013) St Petersburg Declaration, Tax Annex, available at $<$ https://www.oecd.org/g20/summits/saint-petersburg/Tax-Annex-St-Petersburg-G20Leaders-Declaration.pdf>

Gonnet, S., Starkov, V., Pletz, A. and Maitra, M. (2014) 'Comparability Adjustments in the Absence of Suitable Local Comparables in Emerging and Developing Economies', Transfer Pricing International Journal, April, available from <http://www.nera.com/content/dam/nera/publications/archive2/PUB_TPIJ_0414.pdf>

Gupta, A. (2014) 'Why Has the IRS Outsourced Microsoft's Transfer Pricing Audit?', Worldwide Tax Daily, 1 December

Hearson, M. and Kangave, J. (2016) A review of Uganda's tax treaties and recommendations for action, ICTD Working Paper 50, Brighton: International Centre for Tax and Development

Hellerstein, W. (2014) 'Designing the Limits of Formulary Income Attribution Regimes: Lessons from the US States and the Proposed EU CCCTB', State Tax Notes 72: 45 
High Level Panel on Illicit Financial Flows (2015) Illicit Financial Flows, AU/ECA Ministers of Finance, Planning and Economic Development

IMF (2014) IMF Policy Paper: Spillovers in International Corporate Taxation

Kadet, J. (2013) 'Worldwide Tax Reform: Reversing the Race to the Bottom', Tax Notes International 69: 1133-6

Kleinbard, E. (2011a) 'Stateless Income', Florida Tax Review 9: 700-773

Kleinbard, E. (2011b) The Lessons of Stateless Income, USC Legal Studies Research Paper No. 11-7, available at <http://ssrn.com/paper=1791783>; also published in Tax Law Review

Lang, M. and Owens, J. (2014) The Role of Tax Treaties in Facilitating Development and Protecting the Tax Base, Vol. WU International Taxation Research Paper Series No. 2014-03

Langbein, S. (2010) 'Cognitive Capture, Parliamentary Parentheses, and the Rise of Fractional Apportionment', Tax Management International Journal 39: 567-605

Langbein, S. (1986) 'The Unitary Method and the Myth of Arm's Length', Tax Notes 17: 625681

Murphy, R. and Sikka, P. (2014) Unitary Taxation: Tax Base and the Role of Accounting, Working Paper 34, Brighton: International Centre for Tax and Development

OECD (2015a) Preventing the Artificial Avoidance of Permanent Establishment Status. BEPS Action 7 Final Report, Paris: Organisation for Economic Cooperation and Development

OECD (2015b) Addressing the Tax Challenges of the Digital Economy. Action 1 Final Report, Paris: Organisation for Economic Cooperation and Development

OECD (2013) Action Plan on Base Erosion and Profit Shifting, Paris: Organisation for Economic Cooperation and Development. This and all the BEPS reports are now available at <http://www.oecd.org/tax/beps-reports.htm>

OECD (2010) Transfer Pricing Guidelines for Multinational Enterprises and Tax Administrations, Paris: Organisation for Economic Cooperation and Development

OECD (1998) Harmful Tax Competition. An Emerging Global Issue, Paris: Organisation for Economic Cooperation and Development

Parillo, K. (2013) 'U.S., India Working to 'Normalize' Competent Authority Relationship, Danilack Says', Worldwide Tax Daily, 25 November

Parillo, K. and Trivedi, S. (2013) 'U.S. Competent Authority Has Harsh Words About India', Worldwide Tax Daily, 4 February

Picciotto, S. (2015) 'Indeterminacy, Complexity, Technocracy and the Reform of International Corporate Taxation', Social and Legal Studies 24: 165-84 
Picciotto, S. (2013) Is the International Tax System Fit for Purpose, Especially for Developing Countries?, ICTD Working Paper 13, Brighton: International Centre for Tax and Development

Picciotto, S. (1992) International Business Taxation, London: Weidenfeld and Nicolson; electronic version available at <http://taxjustice.blogspot.be/2013/06/internationalbusiness-taxation.html>

Public Accounts Committee (2016) Corporate Tax Settlements, document HC 788, 23 February, UK House of Commons

Sadiq, K. (2014) Unitary Taxation of the Finance Sector, ICTD Working Paper 25, Brighton: International Centre for Tax and Development

Siu, E., Nalukwago, M., Surahmat, R. and Valadão, M. (2014) Unitary Taxation in Federal and Regional Integrated Markets, ICTD Research Report 3, Brighton: International Centre for Tax and Development

Unilever Kenya (2005) Unilever Kenya Limited v. Commissioner of Income Tax, eKLR, Kenya High Court, Income Tax Appeal 753 of 2003

UN (2013) United Nations Practical Manual on Transfer Pricing, available at <http://www.un.org/esa/ffd/tax/TransferPricing/index.htm>

Vann, R. (2010) 'Taxing International Business Income: Hard-Boiled Wonderland and the End of the World', World Tax Journal 2: 291-346

Wells, B. and Lowell, C. (2011) 'Tax Base Erosion and Homeless Income: Collection at Source is the Linchpin', Tax Law Review 65: 535-617 


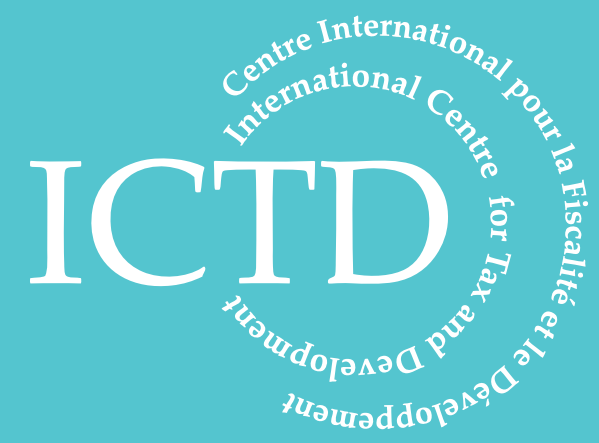

International Centre for Tax and Development at the Institute of Development Studies

Brighton BN1 9RE, UK

T: +44 (0) 1273606261

F: $+44(0) 1273621202$

E: info@ictd.ac

www.ictd.ac 